\title{
Indonesia: Utilization of completed operations research studies
}

Meiwita B. Iskandar

Population Council

Subadra Indrawati

Follow this and additional works at: https://knowledgecommons.popcouncil.org/departments_sbsr-rh

Part of the Demography, Population, and Ecology Commons, Health Services Research Commons, International Public Health Commons, and the Maternal and Child Health Commons

How does access to this work benefit you? Let us know!

\section{Recommended Citation}

Iskandar, Meiwita B. and Subadra Indrawati. 1996. "Indonesia: Utilization of completed operations research studies," Final Report. Jakarta: Training and Development Center for Biomedical and Human Reproduction, National Family Planning Coordinating Board, and Population Council. 


\section{INDONESIA: UTILIZATION OF COMPLETED OPERATIONS RESEARCH STUDIES}

\section{FINAL REPORT}

Meiwita B. Iskandar

Subadra Indrawati

PC in house project \#03286

TRAINING AND DEVELOPMENT CENTER FOR BIOMEDICAL AND HUMAN REPRODUCTION NATIONAL FAMILY PLANNING COORDINATING BOARD

THE POPULATION COUNCIL

ASIA \& NEAR EAST OPERATIONS RESEARCH AND

TECHNICAL ASSISTANCE PROJECT 


\section{ACKNOWLEDGMENTS}

This project was conducted with support from the Population Council's Asia and Near East Operations Research/Technical Assistance (ANE OR/TA) Project. The ANE OR/TA Project is funded by the United States Agency for International Development, Office of Population, Health and Nutrition, under Contract No. DPE-3030-C-00-0022, Strategies for Improving Family Planning Service Delivery. The authors would like to thank Dr. Hasan M. Hoesni MPH, Head of Center for Biomedical and Human Reproduction Research of the National Family Planning Coordinating Board (BKKBN) and other bureaus of the BKKBN for their support and assistance. Special thanks are due to Dr. Valerie J. Hull, Catherine Vickers, and Jeremy Shiffman for their editing advices, and Herna Lestari for her assistance in typing and preparing background materials 


\section{Table of Contents}

ACKNOWLEDGMENT $\ldots \ldots \ldots \ldots \ldots \ldots \ldots \ldots \ldots \ldots \ldots$ ii

1. INTRODUCTION $\ldots \ldots \ldots \ldots \ldots \ldots \ldots \ldots \ldots \ldots \ldots \ldots \ldots$

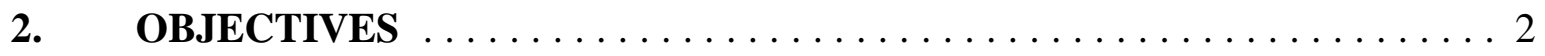

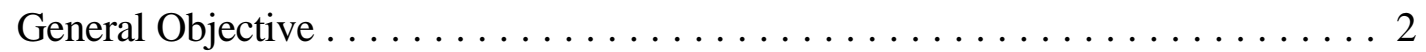

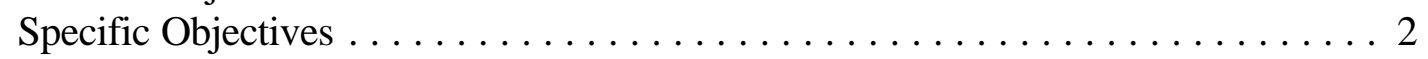

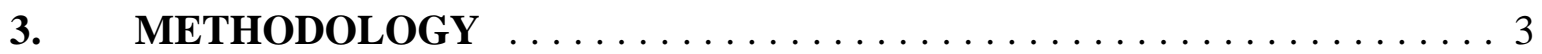

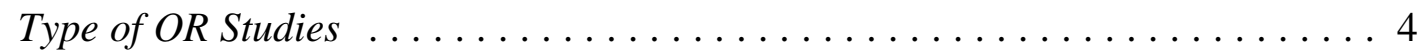

Type of Respondents ............................. 4

Analysis .................................... 4

A framework for analyzing OR utilization $\ldots \ldots \ldots \ldots \ldots \ldots \ldots \ldots \ldots$

(A) The Research Product ....................... 4

(B) The Scientific Network ....................... 4

(C) The Researcher and Policy-Maker Relationship ........... 5

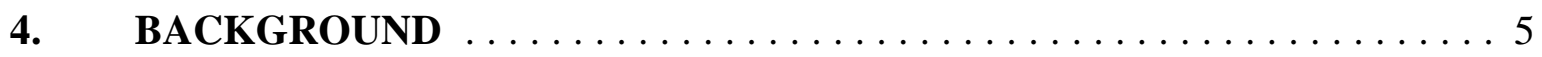

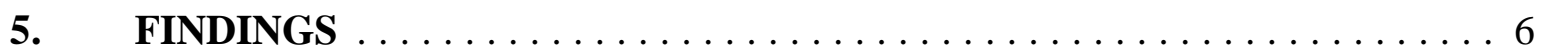

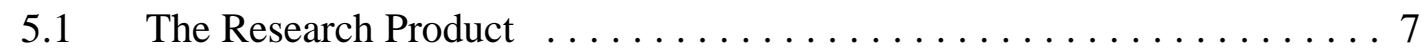

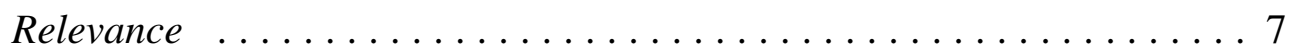

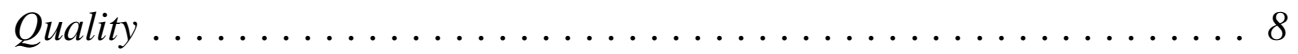

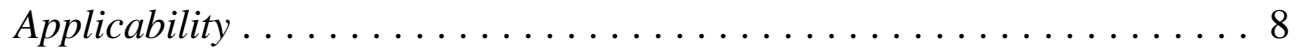

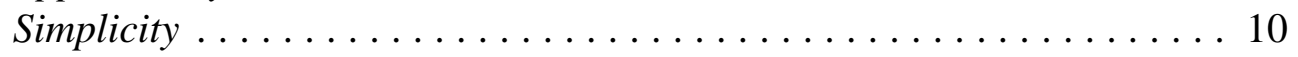

Cost-effectiveness .......................... 10

5.2. The Scientific Network ........................ 11

5.3. The Researcher/Policy-maker Relationship $\ldots \ldots \ldots \ldots \ldots \ldots \ldots 11$

Partnership .................................. 11

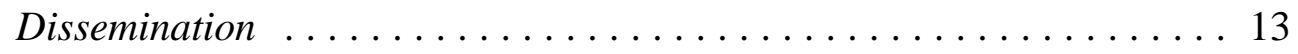

Gender Issues . . . . . . . . . . . . . . . . . . . . . . 15

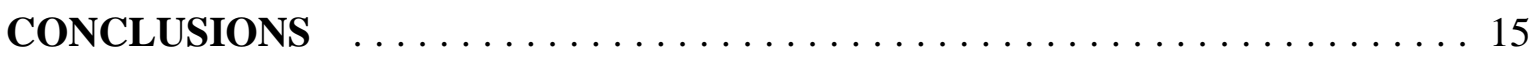

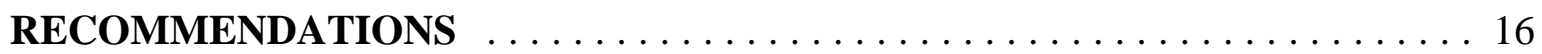

\section{REFERENCES}

\section{APPENDICES}

Appendix A. List of Research Reports Collected

Appendix B. Type of OR Studies

Appendix C. Type of Respondents

Appendix D. List of Selected OR Studies 


\section{INDONESIA: Utilization of Completed Operations Research Studies}

\section{INTRODUCTION}

In the past eight years, many operations research (OR) in family planning programs had been implemented to increase the availability, accessibility, and acceptability of services desired by family planning users. In addition to that, OR has been employed to improve quality and sustainability by studying the performance, efficiency, and effectiveness of services delivered by providers. Nonetheless, relatively little is known about the true effects of OR studies in identifying and solving program problems in order to support the planning and coordinating functions of a particular program.

An indicator of OR effectiveness is the extent of which OR results/recommendations are utilized by managers and policymakers to improve existing delivery activities and plan future ones (Fisher et al, 1991:66). Utilization is closely inspired by information dissemination, and therefore the process of OR is actually incomplete unless sufficient attention is given to information dissemination and utilization (ibid, p.64). On the other hand, it is realized that to measure utilization of the OR results is not simple. Most of the times OR study results were not accepted completely nor implemented immediately to change an entire program. In another case, it might not be the results but the OR process that should be adopted to identify problems and alternative solutions.

In August 1989, USAID signed its last bilateral assistance agreement with the National Family Planning Coordinating Board (NFPCB), known as "BKKBN" (Carpenter-Yaman, 1990:1). The family planning program in Indonesia was considered as "ready to graduate" from AID support, which meant a substantial reduction of AID support to Indonesia was already on its way. Between 1990 and 1995, AID support to OR studies in Indonesia was narrowed formulating plans for the national implementation of a mature family planning program, in contrast to supplying sufficient quantities of contraceptives at the village level services. In this context, the Office of Population and Health has put OR as the heart of the 1989-1994 strategic plan, resulting in the initiation of the Asia Near-East Operations Research and Technical Assistance (ANE OR/TA) in fiscal year 1990, under the global umbrella project "Strategies for Improving Service Delivery." The five-year contract was competitively awarded in July 1990 to the Population Council. ${ }^{1}$ Specific project activities consist of: (1)

\footnotetext{
1) The Asia OR/TA project will be continued for another five-year period (1995-2000) under a new contract (with or without the same contractor).
} 
development and implementation of OR subprojects to respond to regional and country-specific needs; (2) dissemination of OR methodologies and subproject results in ANE countries; (3) technical assistance to solve delivery problems without formal OR studies; and (4) institutionalization of OR as a problem-solving tool for family planning managers (Trayfors, Schuler and Blomberg, 1994: vii).

The NFPCB or BKKBN officials were actually quite eager to carry research, as reflected in the 1984 set up of three centers: the Center for Biomedical and Human Reproductive Research, the Center for Population and Family Planning, and the Center for Family Welfare (BKKBN \& UNFPA, 1991: p.7). Recently, these centers have been reorganized into further development of four centers: Center for Biomedical and Human Reproductive Research (PUBIO), Center for Program Training of Employees and Workers (PULAP), Center for Population and Development (PULDU), and Center for Family Welfare Development (PULIK). These centers have conducted collaborative activities with various universities and NGOs in implementing research including OR studies in the past decade.

The Population Council, in close collaboration with PUBIO, was requested to assess the extent to which the goal of OR - utilization of operations research results - is fully realized. As a result, this assessment highlighted 26 OR studies mostly carried out between 1988 and 1995 (see Appendix D). Funding support for this activity is provided by the 1995-1997 extension phase of USAID-supported ANE OR/TA Project for Indonesia.

\section{OBJECTIVES}

\section{General Objective}

Evaluation of the utilization of past OR studies to improve planning, coordinating, training and evaluation functions of program managers in attaining family planning program policy improvement.

\section{Specific Objectives}

(1) Obtaining a description of past and on-going OR studies and document listed follow-up actions recommended by these studies;

(2) Obtaining information on the utilization of the above OR results/recommendations by policy makers and managers in Indonesia; 
(3) Obtaining information on any follow-up research, formal policy change, piloting of interventions based on previous OR recommendations, and other activities which can be related to prior OR research results;

(4) Identification of barriers in the optimal use of the OR results and analysis of conditions under which OR results are optimally used;

(5) Provision of recommendations concerning the design of a follow-on OR project in the region.

\section{METHODOLOGY}

The study began in April with searching for OR studies conducted under the ANE/OR TA contract 1992-1995. Besides the Population Council's ANE OR/TA project, there are other sources of funds for OR in Indonesia, therefore, additional OR activities funded directly by USAID, the World Bank, Asian Development Bank, and UNFPA in late 1980s and early 1990s were also included. The final list of 26 OR studies, which were screened out of 79 project reports collected, did not cover all OR studies which have been conducted in Indonesia, but has covered a wide range of topics (see attached Appendix A). After the collection of OR reports was completed, and a list of summaries was assembled, the semi-structure questionnaire was pretested, and then individual interview was administered between May 23 and July 31, 1996. The list of OR study titles was given to the respondent before the interview to refresh memory about the problem studied. Once the respondent recognized the title, a summary of that particular OR was provided to revive details of that OR process, results and recommendations. During the interview, consent was sought from the respondent to record the interview into a tape-recorder. On average, the length of interview ranged between 35 to 45 minutes for each respondent.

Questions in a semi-structured questionnaire were designed to address the following aspects: dissemination forum (the concerned audience), utilization of OR findings, perceived quality and scientific recognition from the bureaucrats and academic network, perceived advantage of results, what were the particular follow-up activities to specific recommendations that have been taken by any division in $\mathrm{BKKBN}$ or $\mathrm{MOH}$, and whether there were other factors in the policy makers world that may affect OR process or results utilization. Another two broader issues on the International OR agenda which were also discussed with respondents were: (1) the policy process, how were policies consensus made across the hierarchical echelons of BKKBN, and (2) gender sensitivity in OR research, and the links to a wider

Reproductive Health research. Data analysis began in August, and report writing began in September 1996. 
Type of OR Studies. Out of 26 OR studies documented in this study, 10 can be classified under Exploratory/Diagnostic Studies; 10 can be classified as Field Intervention Studies, and 6 can be classified as Evaluative Studies. These OR studies were implemented between 1988 and 1995 (see Appendix B).

Type of Respondents. A total of 38 THE NFPCB officials who work in the two headquarter offices of THE NFPCB Halim and THE NFPCB Cawang were interviewed. From the highest (Echelon-1) to middle-manager administrative rank (Echelon-3), the interviews successfully involved 3 respondents from Echelon-1, 14 respondents from Echelon-2, and 21 respondents from Echelon-3. Genderwise, all Echelon-1 respondents are males, only 4 out of the 14 Echelon- 2 respondents are females, but 8 out of the 21 Echelon- 3 respondents are females (see Appendix C). Due to the recent repositioning of BKKBN officials at the headquarter office, and the fact that there is a high mobility between officials' position at central, regional and province levels, the selection of respondents at BKKBN has included officials who expressed their opinion on behalf of their divisions/bureaus (current position), and those who expressed individual opinion only because they are no longer in the positions they had before.

Analysis. The collected 26 OR studies were descriptively examined, compared one to another and classified according to OR types (Exploratory/Diagnostic Studies; Field Intervention Studies, and Evaluative Studies). For each OR study, a 1-2 page summary consisting of title, objectives, methodology, site(s), institutions and donor agency involved, findings and recommendations was composed (see Appendix D). Then, a simple content-analysis across all research summaries was conducted using a simple framework described below.

A framework for analyzing $\boldsymbol{O R}$ utilization. Based on available literature on linking health research to policy, this study adopts Fitzroy Henry's framework from Council on Health Research for Development (COHRED) which focuses on three elements of the research/policy link: (A) the research product; (B) the scientific network; and (C) the researcher/policy-maker relationship (Henry, 1996:1,4).

(A) The Research Product. This includes aspects such as relevance of OR to the country specific needs, quality of research work, applicability of research findings, simplicity of research tools, and cost-effectiveness of research recommendations.

(B) The Scientific Network. This views whether the OR was perceived as a comprehensive research that can provide answers to the why and how to improve questions raised by policymakers, and recognized by other researchers in the scientific network. 
(C) The Researcher and Policy-Maker Relationship. This covers interpersonal interaction and communication aspects such as whether the researchers tried to identify the interests of the policy-makers and middle-managers, whether there was a mutual trust between researchers and policy-makers, and whether there was assurance that research findings were disseminated not only in peer-review scientific or local journals but also in other mechanisms that bring research findings closer to policy-makers.

\section{BACKGROUND}

The problem of dissemination of research findings and underutilization of research recommendations was already mentioned in 1990 by the NFPCB (BKKBN) while preparing the project agreement between the Government of Indonesia and the United Nations Fund for Population Activities (unpublished document of UNFPA's project INS/91/PO3 entitled "Strengthening Family Planning Research for Programme Management at the Provincial Level." This document mentioned that more than 500 research studies in the field of population and family planning have been conducted over the past two decades (NFPCB \& UNFPA, 1991:7). Although the results have contributed substantially to the policy formulation and assisted in the successful implementation of the national family planning program, it is realized that in the near future a more systematic and programme oriented OR is needed to accommodate changes due to the rapid growth and level of sophistication of current family planning programs.

Retrospectively, in the 1980's the NFPCB had already commented that whereas some studies generated by research institutions are found to be very useful, many studies produced by these institutions are too theoretical and have little practical or programme value for the NFPCB (NFPCB \& UNFPA, 1991: p.7). Therefore, in 1984, under the Deputy for Programme Development, the three research centers (the Center for Biomedical and Human Reproductive Research, the Center for National Family Planning Policy Development, and the Center for National Family Planning Studies) had been given formal responsibility for organizing, conducting and collaborating research and evaluation activities (ibid, pp.7-8). Between 1984/85 and 1988/89 (Repelita IV), the NFPCB research plan included the development of its own capacity to conduct and administer/manage research studies even at the provincial level, while simultaneously continuing to support outside research institutions to conduct collaborative research studies involved in more programme oriented operations research (ibid, p.7). 
Evidently a number of OR studies were conducted between 1984/85 and 1988/89. Yet, the number was perceived as far too small for the benefits of the programme implementation at the provincial levels. The GOI and UNFPA project agreement for the period of 1991-1994 incorporated a plan to strengthen the manpower capacity at the provincial level to identify priority issues of local concern for operations research and to bring solutions/remedies. In addition to that, the agreement included supports to conduct secondary data analysis as there are voluminous data sets at the provinces that are not fully utilized for programme operations/management. This UNFPA support for Repelita V documented another important aim, "to utilize OR findings in formulating program intervention immediately after the OR studies have been completed," which reflects the recognition of the goal of OR activity (NFPCB \& UNFPA, 1991:8).

It is expected that by the end of the project there would be a sizeable increase in the utilization of OR results by the central and provincial NFPCB, and by the provincial researchers, in support of the family planning delivery services improvement as well as in the formulation of future policies and program strategies development (NFPCB \& UNFPA, 1991:9). However, entering the Sixth Five-year Development Plan (REPELITA VI) 1994/951998/99, although the overall strategy does not depart much from the previous Repelita V, there were policy changes at the headquarter that place restriction on NFPCB's research centers which will not allow the above centers to conduct in-house operations research as well as training and management of research projects anymore. All research work must be contracted out to a third party, to forge a sustainable link with research institutions and non-governmental organizations (NGOs).

\section{FINDINGS}

The most significant discovery was the fact that none of the 38 respondents could identify specific policy changes resulting directly from the utilization of an OR study, although a few of the respondents felt that she self-sustained KB Mandiri and the Norplant studies (i.e., the Use-Dynamics Diagnostic and Evaluation Studies, the Situation Analysis of the Service Delivery Points in the NFPCB's Long-term Method Priority, and the most recent Norplant Removal Assessment Study) have great practical applicability to their work and the core information derived from these studies have strongly inspired the policy implementation of $K B$ Mandiri and Norplant strategy development. Nonetheless, when asked further, they revealed that the political agreement seemed to be the sole independent factor that has the final say at the end, while policy changes occur within a small web of interacting forces. Despite how excellent OR recommendations are, the chances for change can only increase when the right 
resource person uses this information to advocate for change and bring it to the attention of those who have the power to actually influence policies and their implementation.

Therefore, the emphasis of this report is not in the presentation of the abstracts/summaries of OR studies (see Appendix D), but more on disclosing respondents' feedback about how OR studies were being carried out, whether OR results were incorporated into the planning mechanism, and to what extent OR findings were disseminated within the NFPCB. As such, the findings are presented in accordance to Fitzroy Henry's framework (1996) for analyzing the dynamic linkage between OR utilization and policy demand (as mentioned in Section 3: Methodology), with three main topics of discussion: (5.1) the research product; (5.2) the scientific network; and (5.3) the researcher and policy-maker relationship.

\subsection{The Research Product}

Relevance - Respondents said that ideally an OR should be a policy relevant study that was implemented based on realities of the policy-makers world, fit into operational program needs, and feasible within the existing policy constraints. Unfortunately, there were still some studies that respondents felt were irrelevant to THE NFPCB's mission. Consequently, respondents found the research activities did not address the major constraints confronted by family planning policy or programs. Typical comments about the underlying cause of inappropriate topic selection were:

"Researchers only know one-eighth of the program, we know $100 \%$ of program development. Undoubtedly their recommendations are irrelevant because we have already reached the score of 8 when they barely accomplish a score of 3."

"The university people [researchers] have different perspectives ... They are more oriented toward theory. The result is that what BKKBN programmers believe to be problems are not captured in the research instruments."

"Researchers often are not familiar with our programs. Therefore, the research problems they selected are often irrelevant to us."

"The problems being researched are not appropriate because operational people are not involved in the identification of problems."

"Example of problems being researched are not pertinent - for instance, the research in Central Kalimantan called 'the role of the Family Welfare Movement cadres (PKK) in raising the performance of the family planning movement in isolated areas.' This is not needed for OR."

"Operations research is not always in harmony with existing programs." 
Quality - The questions regarding the quality of research design, instruments, training, data collection procedures, data analysis, and data presentation were answered by a few respondents only. It was difficult to assess whether this was due to recall problems or unfamiliarity with research design and methodology. Most of the comments pertained to the quality of research were as follows:

"(1) too many variables were collected and not fully analyzed, resulting in superficial or descriptive analysis, and also indicating that the researchers were not well-prepared; (2) methodology was inappropriate in attaining the study objectives; and (3) training was not directed at the right target groups, i.e., in the Situation Analysis of Government Run Service Delivery Points for Family Planning in Indonesia, training on counselling was imparted for doctors and midwives while from NFPCB's mission it would be more appropriate to have family planning cadres receive the training since they are the ones who 'condition' the socio-cultural environment in the field."

Another notable quality problem according to program managers was arising directly from the quality of research recommendations which frequently are vague, obscure or inappropriate:

"The researcher does not know the situation in the field, with the result that the recommendations given are abstract."

"The recommendations offered are not focused."

"After research has been conducted, we still cannot see what must be done. So, research results remain nothing more than research results."

Basically, a common theme was voiced by the NFPCB officials in reference to the utility of most OR recommendations. Often the recommendations were perceived as not being clear and lacked of obvious utility. Specifically mentioned were recommendations that merely were a restatement of the problem. These kinds of recommendations created a feeling of frustration in those who "work in the trenches" and feel that they already possess a keen awareness of what the problems are. Those people who cope with real problems on a daily basis expect that researchers should offer a solution and not just a restatement of the problem. The utility of an OR recommendation also seemed to be decreased when the recommendations called for additional study in lieu of offering an original plan for problem resolution.

Applicability - The majority of respondents still felt that OR studies are useful in supporting on-going family planning program improvement. The evidence of instant usage of OR findings were not denied by most of the respondents. A number of comments indicated that research 
is indeed having some impact on NFPCB programs, but difficult to point out which study titles contributed to program planning and policy changes. In brief, OR findings was said to have affected various IEC and training programs.

One of the studies that was most frequently mentioned was the OR on self-sufficient family planning or the social marketing of the Blue Circle (KB Mandiri) in Yogya, Bali and North Sulawesi, as expressed below:

"The operations research on self-sufficient family planning services with the Blue Circle (LIBI) was very successful. The proof is that beginning with three provinces, the program spread to 13 , and the program is now entrenched."

"The operations research on self-sufficient family planning in three provinces (Yogyakarta, Bali and North Sulawesi) was very good and successful."

"Operations research on self-sufficient family planning became a national policy."

Respondents indicated that other studies also have had an impact on programs, including research concerning the role of rural midwives in Lampung, the implant use dynamic study, and the situation analysis of government run service delivery points.

Most respondents mentioned that timeliness of presentation of results can also affect the applicability of OR findings. Late presentation of research means that often findings are out-of-date, or reports cannot fit into program planning. There were several comments on the issue of late presentation:

"Problems brought up for research are not necessarily completed within one year. In the meantime, the problems have already changed."

"There is a problem that results are presented too late. For instance, research from 1992 is not presented until 1994."

"The program has already started when the research results appeared, with the result that they are not used."

Many respondents mentioned that $O R$ results presented just before the National Planning Meeting (Rakernas) in the month of March, or during the BKKBN internal Pre-Program Review and Annual Program Review meeting to reevaluate research, which is held 6 months before the Rakernas, are more likely to have program impact than research presented at other times of the year. The NFPCB reviews selected research results in the Pre-Program Review and Annual Program Review meetings, in which policy-makers and middle-managers meet and 
communicate research findings to provincial representatives. These selected research findings and recommendations are then used as references in the program planning process. If a particular research is presented just before these events, it is more likely to be salient in the minds of relevant officials as they go about planning the following year's programs. If presented at another time of the year, the research may well be buried amidst hundreds of other operational matters.

Simplicity - In general, the simpler the research design and strategy, the greater the chances of the result being readily understood and effectively implemented. While some researchers feel that "high-tech" research, using very complex research tools, would enhance the quality and respectability of the endeavor, the policy makers felt differently and commented as follows:

"Those who carry out the research do not fully understand the situation in the field. "

"The researchers are not sharp in seeing the weaknesses in the field."

"Those who conduct the research do not fully understand how program interventions and activities are carried out."

"...research results are presented in a form that is difficult to understand, because they are presented in academic style."

Cost-effectiveness - The utilization of OR recommendations for new interventions, training and measures must be ideally cost-effective and affordable for provincial health care providers and consumers alike. Most of the respondents seemed to perceive that replication of an OR or scaling-up of OR activities in more provinces are evidence of OR 'high cost-effectiveness' and an indication that the suggested recommendations are well placed to result in changes in policies, programmes or interventions. Training is considered by many as a 'cost-effective' OR recommendation to be implemented.

A respondent stated that adoption and incorporation of costly OR recommendations which are too theoretically oriented would be just an exercise in futility. The amount of budget allocated for OR always look huge during program planning. Another respondent acknowledged that many of the NFPCB field-staff who are not interested in research activities perceive that research is not a justified investment, only an additional cost and wasted money. A suggestion made by a respondent: "recommendation should be directed toward on-going improvement of existing infra-structure by local provincial officers. Otherwise, most OR 
activities will only be supported during the project period. When the project comes to its end, local field staff do not pay attention anymore."

\subsection{The Scientific Network}

Professional Associations seemed to have a very effective clout with family planning policy makers. In the past decade the NFPCB has built very close relationships with professionals from the Indonesian OB-GYN Association (POGI), the Indonesian Medical Doctor Association (IDI), the Indonesian Midwives Association (IBI), the Indonesian Sociologist Association (ISI) and the Indonesian Pharmacologist Association (ISFI). Some of the OR studies involved members of these professional associations and they also presented the OR findings in national and international conventions and conferences to convince their colleagues of the validity of their research findings and of their usefulness as foundations for policy options.

The NFPCB policy-makers are also well-aware of the importance of the integrated approach, because many of the determinants of family planning use are recognized to be outside the medical sphere. Most of the respondents agreed that researchers should be more engaged in multi-disciplinary studies that can provide comprehensive answers to operational questions raised. The new policy that prohibits the conduct of in-house studies is very encouraging toward more objective and multi-discipline OR studies. On the other side, the operational middle-managers also communicated a great demand to learn more about OR methods and use, so that they can better understand the scientific interpretation of OR findings and will be more confident in participating during OR discussion. They preferred the internal research staff from the three research centers within the NFPCB to organize regular refreshing sessions to fulfill these needs.

\subsection{The Researcher/Policy-maker Relationship}

Partnership - Experience has shown that when policy makers have been involved from the early stages of the research process, and their input has been sought at each progressive stage, the findings have a higher chance of resulting in policy change. In recognition of this issue, the NFPCB has already created a forum of partnership where interpersonal interaction can occur and direct communication is assured. One person commented, for instance: 
"The National Planning Meeting (Rakernas) is on the 15th of March. Before that, from the 12th to the 14th, the Deputy for Program Development has a meeting in which all research results are presented by the researchers. We sit together and go over the results of research we think are in accordance with policies. Following that, in the National Planning Meeting, salient research results can become references for the upcoming year's policies."

The middle-managers of operational bureaus such as: Bureaus of Contraception, Community Institution Development, Information and Motivation, Physical Family Welfare Maintenance, Non-physical Family Welfare Maintenance, and Population Development are the ones in charge of implementing field activities. They are actually the internal clients of the researchers that should be involved from the early stages of the research process, and their input should be sought at each progressive stage. Many of these middle-managers communicated that in practice their opinion or inputs rarely sought in the planning stage of most of the OR studies conducted by in-house research centers in the past. As a result, a program manager stated that "as anticipated, both the proposal and study findings have no relevancy toward program needs." However, the program manager admitted that the operational bureaus are responsible also for this flaw because subsequently they seldom invite the researchers (from internal centers) when they discussed programmatic problems.

Most of the middle-managers of these Bureaus felt that anyone of the three research centers within the NFPCB should organize and be in charge of documenting various OR proposals that have been developed in the past, summarizing the previous OR findings, and listing OR recommendations that can be implemented for different purposes in relation to their daily programmatic problems.

Other ominous situations that contribute to a wider gap between the planner of OR research activities (the Centers or Pusat-pusat within the NFPCB) and the operational middlemanagers (the Bureaus or Biro) are: (1) Bureaus encounter very rapid programmatic changes in accordance to political changes at the top strategic planning level, while OR planning activities are always behind (considered "too slow"); and (2) Bureaus feel that selection of research counterparts were poorly done because centers did not prepare a solid qualification criteria nor a list of potential topics. A critic from a program manager as an internal client of the Pusat-pusat: "it seems that most of our research are not designed based on needs assessment but based on the amount of available budget allocated."

In regards to outside researchers, middle-managers seemed to underestimate the researchers' capabilities in defining appropriate research problems. Nevertheless, they admitted 
that technical assistance is needed for determining proper study design and methodology. Many consider the age of the principal investigator as quite influential. Respondents stated that older researchers often have a fixed opinion and they are more text-book thinking than the younger ones. Consequently, often the NFPCB's officers had difficulties in explaining what they wanted to explore. The study ends up without capturing the dynamic of the problems in the field. In contrast, if the researcher is considered as a 'newcomer,' the respondents also doubted that the resulting OR can provide answers to the why and how to improve the program.

Many of the agencies involved with research have a central concern with quality of care. This concern propels the selection of topics, such as quality of service delivery, safety issues and Norplant follow-up. The NFPCB policy-makers, on the other hand, may be primarily interested in information useful for increasing or maintaining contraceptive prevalence or, more recently, for fostering the prosperous family (keluarga sejahtera) program. It is interesting to note that one area of research where agency and the NFPCB interests coincide - the provision of self-sufficient family planning services - is also the research area most frequently mentioned by BKKBN officials as having had program impact. The point is that in order for operations research to be utilized fully, the basic missions of external research agencies and the NFPCB need to be in sync. The planning of an OR should bring with it a promisory note that quality improvement will be attained yet still maintain current program coverages.

Dissemination - A research findings can be useful only if they are known to people who can use them. Problems with dissemination and presentation format were mentioned as a source of under-utilization. One main piece of evidence that these are problems is the fact that many respondents - research staff from the internal research centers who more than anyone else in the BKKBN should know about the research that has been conducted - were not familiar with any of the studies on the list of OR projects presented to them. Direct comments also indicated problems with dissemination:

"When results are presented, those invited are not the users or the appropriate people." "The dissemination of results is insufficient."

"The distribution of OR results should be more comprehensive; not just to one unit only or only those who want to know."

The dissemination method mostly used was seminar and workshop settings where the findings were officially launched and released for use. Such a seminar was attended by a limited number of officials at the headquarter office, and further limited by the fact that 
invitation to attend the seminar or workshop was only circulated to units that are perceived as having "relevant" activities or mandates. It was common that those division/units invited did not have the right staff available to attend the invitation, and therefore the division was represented by a staff member who did not have any interest at all or could not make any decisions or contributions during the seminar/workshop.

At the headquarter, another cause of the unlinked OR study to the programmatic problems is the fact that there is a very high chance that the invited person did not show up during a research proposal seminar or presentation of research findings because they preferred to travel instead. There seemed to be a pattern of a higher level of travel by supervisory personnel. People in these positions were predominantly male and from echelons 1 and 2. One respondent felt that such a trend was genderwise influenced by the socio-economic/cultural values that a male is more often a "breadwinner" of the family ("pria adalah pelengkap penderita dalam keluarga"), while a female staff has less pressure since her earnings are merely a supplement to her husband's income ("sedang wanita hanyalah pelengkap penyerta"). The problem was that often the substitute person who attended an OR study proposal might not have the substantial knowledge of the operational problems. As a consequence, there are missed-opportunities for inserting operational problems during the problem formulation (proposal seminar), and similar risks for applying relevant OR recommendations (during OR results seminar), because the right person did not attend the researcher's presentation.

Presentation format may not only be an issue pertaining to written reports, but also to the way results are introduced in forums conducted after the research has been completed. The use of audio-visuals and simple messages may facilitate the understanding of the research by end-users, and therefore increase the likelihood they will apply research results in their programs. Researchers need to devise other mechanisms apart from journal publications to bring research findings to the attention of policy makers and other health professionals. Research report should be clear and succinct, highlighting their relevance and the applicability of the findings. Summaries of such findings should be written in non-technical jargon as one respondent said:

"We do not read all the results of the research."

"This is in part because in the report there is no executive summary."

The Bureau of Information Networks and Documentation (BIJID) tried to gather research reports from all centers within the $\mathrm{BKKBN}$, but seemed to be frustrated with the results, as reflected in the following: 
"We are active in approaching [centers with research reports] in requesting them to place these reports in the box that has been prepared for this purpose, but this mechanism does not work."

Gender Issues. The NFPCB has recently expanded its scope of activities into reproductive health issues (Suyono, September 1996). Based on the reactions to questions of gender issues, it seems that majority of the staff have not come to the mainstream thinking of 'coming to a better understanding of the gender issues will affect family planning, reproductive health and family welfare.' Many of the respondents admitted that they are not aware of any family planning research that consider gender issues of importance. A respondent commented: "gender issues are only discussed by the 'upper level,' those at the 'bottom' never have those kinds of conversations." Another remark is: "gender issues can only be studied in urban areas, they are irrelevant topics for rural areas." But a few other respondents recalled that they had heard about the "male involvement in family planning" study, but were not able to elaborate further about what were the important gender issues for family planning program attainment.

\section{CONCLUSIONS}

Out of 79 project reports collected, 26 OR reports were further scrutinized. Ten of them can be classified under Exploratory/Diagnostic Studies; another ten as Field Intervention Studies, and six as Evaluative Studies. These OR studies were implemented between 1988 and 1995. Details of objectives, methods, findings and recommendations were summarized and displayed to 38 selected respondents within the NFPCB. Interviews were conducted using a semi-structured qustionnaire asking about the utilization of OR findings, barriers and recommendations. The results indicate that information on the utilization of the above OR results/recommendation are inseparable between one topic and another, because all of the respondents preferred to foresee the utilization in a global way. Specific information on follow-up, policy change, interventions based on previous OR results are scarce. This is due in part to insufficient attention to document proposals, research reports, and utilization.

Eight barriers in optimal use of the OR results are presented: (1) topics are perceived irrelevant; (2) quality of recommendations are vague; (3) research findings are either presented out-of-date, or no longer able to influence programs that are already in the process of being implemented; (4) too complex research tools; (5) perceived not cost-effective; (6) weak researcher/policy-maker relationship; (7) not all research reports are disseminated widely; and (8) reports are not presented in an easily readable format. 
There are two stands within the policy process in the NFPCB as an organization. First, it is common among policy-makers and operational middle-managers to express a skeptical feeling about the ability of research to effectively address the family planning problem. This significantly affects the utilization of OR recommendations into their policy planning process. Second, those who play the role of internal research staff put a high premium on research they confidently believe will help solve operational problems. At the same time, the policy makers and middle-managers view the internal research staff as not being very perceptive about field-operational problems. This situation has led to a silent crisis of mutual trust between the middle-managers or policy-makers and the researchers (internal staff within the NFPCB centers or outside researchers).

There are several causes of the above problem. A direct cause of this problem may be inadequate coordination and communication between the researchers and the middle-managers or policy makers on research topic selection. A second cause may be inherent within the operational bureaus: middle-managers invited to be involved in research planning may not always be able to articulate the genuine needs from the field. There may also be a third, more fundamental problem that gives rise to this discrepancy, one more difficult to correct. The research goals of the agencies funding the research and the NFPCB middle-managers may be different because the two sides have divergent organizational agendas.

One of the most frequently mentioned barriers is limited dissemination of research summaries. This is certainly in contrast to what Fisher et al (1991:66) said, "the process of operations research is not complete until the results are disseminated fully and every effort has been made to have them used." Respondents expressed the belief that previous OR findings and recommendations were mostly communicated within a small circle of staff within the two headquarter offices only. That means the dissemination strategy has not fully considered: (a) different potential users of the findings and recommendations; (b) which findings are of particular interest to a given user group; and (c) a variety of media channels to reach each potential user group. The potential users groups can be categorized into: first, the chief executive officials of the related program at the headquarter (policy makers and mid-level operational managers, which in the NFPCB setting means echelons I, II and III). The second group is the provincial and district chief officials. The third, fourth and fifth groups are academicians, public/community/grassroots leaders, and service deliverers.

A majority of respondents still prioritize $\boldsymbol{O R}$ and believe that, in principle at least, OR is practical and useful to program development, as expressed in the following statements: 
"[Operational research] offers immediate input to managers..."

"...the results [of operations research] offer support for program planning."

"[Operations research is useful for] straightening out conditions in the field."

"If data is accurate and informative, an operations research is quite useful for planning, solving problems, suggesting strategies and for other matters."

But, as Porter (1995) also concluded, "changes in policy and policy implementation rarely result from a linear process of generating research, laying out policy options, choosing between alternatives, and evaluating the implementation of the selected option. Changes occur when the policy makers/middle-managers present a 'window of opportunity' that can be grasped by the ingenious researchers to propose reform for changes. A dynamic advocacy with those who can actually influence policies plays an important role. Otherwise, if the researchers do not familiarize themselves with the internal invironment and interests of the policy makers and program managers, the following apply:

"Indeed they are experts in research. But they do not know the situation within the NFPCB ... our response to their results [ends up being]: Is this all there is? We already knew that."

\section{RECOMMENDATIONS}

To improve OR utilization, based on the lessons identified in this study and practical suggestions from the respondents, the planning of OR needs to follow the following guidelines:

1. Policy-makers and program managers should be given an opportunity to learn about the benefits of $O R$ on daily program functioning including the methods and 'language' of $\boldsymbol{O R}$. This will promote a better appreciation and provide the skills to actively participate in the formulation of relevant OR problem.

2. Investigating researchers must possess a familiarity with the interests of the policymakers and program managers, and be able to propose advocacy for necessary policy change. This will bring together research/analytic work and policy advocacy in a more interactive way.

3. Research centers within the NFPCB should be involved in the preliminary and ongoing program meetings where policy-makers and program managers discuss their daily operational problems. Participation in these meetings will allow them to discover essential OR problems that will be more relevant to program goals. 
4. The content of $O R$ should strive for simplicity in design to promote greater acceptability and use. Academic language should be minimized, in favor of simple, concise discussions. At seminars where results are presented, audio-visual aids should be used to ensure that those in attendance understand clearly the research results and recommendations.

5. Recommendations should provide clear and realistic interventions including the achievable measures of change. This means even managers in the field should know immediately what action they need to take upon reading reports.

6. Research findings and recommendations need to be presented in a timely manner and take advantage of pre-existing key decision-making forums. This is to avoid the often recurring situation where results are presented long after the programs they might have influenced have already begun to be implemented. In order to reach the key people, some of the existing forums are:

a) The National Planning Meeting in March (Rakernas);

b) Pre-Rakernas meeting (also in March) to review research, chaired by Deputy for Program Development;

c) Mid-year research review meeting (October/November), also chaired by Deputy for Program Development;

d) Frequent national and or regional meetings, not necessarily concerning research, in which officials from the field gather to discuss program developments and planning.

7. Researchers should transform OR findings into 'user-friendly' formats or 'language'. Summaries and abstracts attract a greater interest of audience by using figure, graphics rather than discription.

8. Presentations should be given to audiences of greater diversity, minimize special interests, and include a broader coalition of participants.

9. OR should make use of existing multimedia that can satellite summaries of OR findings to provincial program managers that cannot attend the centralized urban meetings. Bureau of Information Networks and Documentation (BIJID) should be included in the research process as this bureau is responsible for collecting and disseminating information within the NFPCB.

10. Balance program initiatives with clients' desires by more analyses of the impact of gender on reproductive health and family welfare. 


\section{REFERENCES}

Carpenter-Yaman, Carol E. "Future AID Support for Population in Indonesia and the Role of Operations Research." Paper presented in the Family Planning Operations Research Asia Regional Conference in Singapore, March 4-8, 1990.

Fisher, Andrew A., John E. Laing, John E. Stoeckel, and John W. Townsend. Handbook for Family Planning Operations Research Design. Second Edition. New York: The Population Council, 1991.

Henry, Fitzroy. "Linking health research to policy: the researcher's role." Research into Action. The Newsletter of the Council on Health Research for Development (COHRED), April-June 1996, Issue 5: 1,4.

Kumar, Sanjeev. Communications Needs Assessment: India. (Draft Final Report). New Delhi: The Population Council ANE OR/TA Project, May 1996.

NFPCB \& UNFPA. Project agreement INS/91/PO3 entitled Strengthening Family Planning Research for Programme Management at the Provincial Level. Jakarta: BKKBN \& UNFPA, January 1, 1991.

Patton, M. Quinn. Utilization-Focused Evaluation. Beverly Hills: SAGE Publications, 1978.

Porter, Robert W. and Novelli. "Knowledge Utilization and the Process of Policy Formation: Toward a Framework for Africa." A paper prepared under the SARA project operated by the Academy for Educational Development, under the support of USAID, Africa Bureau, January 1995.

Suyono, Haryono. Speeches on "Scientific Meeting entitled Reproductive Health and Welfare" and a meeting on "Implanon's Marketing Development" ("Pokok-pokok Sambutan pada Temu Ilmiah Reproduksi Sehat Sejahtera dan Pertemuan Kerja Pengembangan Pemasaran Implanon"). Jakarta: Kantor Menteri Negara Kependudukan/BKKBN, 30 September 1996.

Trayfors, Bill, Sidney Schuler and Robert Blomberg. "Evaluation of the Asia/Near East Operations Research and Technical Assistance (ANE OR/TA) Project (936-3030)." POPTECH Report No.94-017-014, December 1994.

Tuladhar, Jayanti. The Highlights of Asia and Near East OR/TA Project Activities in Indonesia (January 1992 - June 1995). Jakarta: The Population Council, June 1995. 


\section{List of Research Reports Collected}

Affandi, Biran et al. Insertion \& Removal of Norplant Contraceptive Implants by Physicians \& Nonphysicians in an Indonesian Clinic. Studies in Family Planning vol. 18, 303-306, 5 Sept/Oct 1983.

Affandi, Biran. Norplant \& Implanon: A Comparative Study. Preliminary Results of Research of Implanon in Indonesia." Jakarta: PUBIO-BKKBN, 1995.

Affandi, Biran. Removal of Norplant by Doctors \& Midwives: A Comparative Study. (Draft I). Jakarta: BKKBN, 1995.

Agustiar, Memet. Improving the Implementation of PPKBD Tasks in Order to Consolidate the Active FP Users in West Kalimantan. Pontianak: BKKBN Kalbar, September 1993.

Anwar, Mochammad and H.R. Siswosudarmo. Comparative Cohort Study Between Norplant and Depoprovera (DMPA) with Special Reference to Bleeding Problems. Yogyakarta: School of Medicine, University Gajah Mada, 1994.

Azwar, Azrul. OR Secure Contraception Teams Mobile Services in Daerah Istimewa Yogyakarta. Jakarta: Perkumpulan Kontrasepsi Mantap Indonesia (PKMI), October 1995.

Basuki, Endang. Improving the Acceptance and Quality of Vs Services Through the Screening Referral and Follow-up of Pre- and Post-Vs Clients. Jakarta: Perkumpulan Kontrasepsi Mantap Indonesia (PKMI), September 1988.

BKKBN. The Implant Survey: Preliminary Key Results. Jakarta: BKKBN, 1989.

BKKBN. Implant Removals: Case Studies in West Sumatra. Jakarta: BKKBN, 1990.

BKKBN and YKB. Integration of Norplant into the National FP Program in Indonesia: Its Management Aspect. Jakarta: BKKBN and YKB, 1988

Bratakoesoema, Dinan et al. The 1992 Norplant Use Dynamic Study in Indonesia. Jakarta: The Population Council, March 1993.

Budiarto, Eko, Ayip Rosidin and Dodih Suryadi. Improving Rural KB Mandiri through Improving the Distribution of Contraceptives, Private Sector Midwives and Community Participation in West Java. Bandung: BKKBN Provincial Office, West Java, December 1994.

Chandra, Budiman and M.A.H. Farouk. Comparative Cohort Study Between Norplant and Depoprovera (DMPA) in Palembang. Palembang: BKKBN, 1995. 
CBD Evaluation Team, Central Java. Program Evaluation: Community Based Distribution $(C B D)$. Semarang: Department of Communications, University DiponegoroSemarang, and The Institute for Mass Communications Research and DevelopmentJakarta, April 1995.

CBD Evaluation Team, West Java. CBD Evaluation, West Java. Bandung: Faculty of Communications-University Pajajaran, and The Institute for Mass Communications Research and Development-Jakarta, May 1995.

CBD Evaluation Team, Bali. Program Evaluation: Community Based Distribution (CBD). Denpasar: Department of Anthropology, University Udayana, and The Institute for Mass Communications Research and Development-Jakarta, June 1995.

CBD Evaluation Team, East Java. Program Evaluation: Community Based Distribution $(C B D)$. Surabaya: Department of Communications-University Airlangga and The Institute for Mass Communications Research and Development-Jakarta, July 1995.

CBD Evaluation Team, Lampung. Program Evaluation: Community Based Distribution $(C B D)$. Lampung: Faculty of Political Sciences-University Lampung and The Institute for Mass Communications Research and Development-Jakarta, August 1995.

CBD Evaluation Team, North Sumatra. Program Evaluation: Community Based Distribution (CBD). Medan: Department of Communications-University North and The Institute for Mass Communications Research and Development-Jakarta, August 1995.

CBD Evaluation Team, South Sumatra. Program Evaluation: Community Based Distribution (CBD). Palembang: CBD Evaluation Team - South Sumatra and The Institute for Mass Communications Research and Development-Jakarta, August 1995.

CBD Evaluation Team, South Sulawesi. Program Evaluation: Community Based Distribution (CBD). Ujung Pandang: Evaluation Team-University Hasanuddin, Ujung Pandang and The Institute for Mass Communications Research and Development-Jakarta, September 1995.

Darmono. Improving KB Mandiri through Village Midwives and Community Participation in Central Java: Evaluation Results 1995. Semarang: BKKBN, December 1995.

Djuarsa S., Sasa; Pinkey Triputra and Jack. Reynolds. Evaluation of the External Quality Assurance System for Voluntary Sterilization and Other Long-Term Contraceptive Services in 12 Provinces of Java, Sumatera \& Sulawesi. Jakarta: The Institute for Mass Communications Research and Development, and University Research, Sept. 1995.

Fisher, Andrew et.al. Norplant Implants in Indonesia. Jakarta: The Population Council, 1995. 
Halim, Kesuma et al. Improving Rural KB Mandiri through Improving the Role of Private Sector Midwives and Rural Community Institutions in East Java. Surabaya: BKKBN Provincial Office, December 1994.

Hanhart, Jannemieke. "Women's Views on Norplant: A Study From Lombok, Indonesia." Norplant: Under her Skin. The Netherlands: Women's Health Action Foundation, 1993, p.27-46.

Hartono, Poejo et al. A Study on Incidence of Side Effect Among Contraceptive Users. Preliminary Report. Jakarta: PUBIO-BKKBN, 1995.

Hendarso, Yoyok. Improving the Role of the Private Sector Midwife through the Improvement of Rural KB Mandiri in South Sumatra. Palembang: BKKBN Provincial Office-South Sumatra and the Socio-Cultural Research Center-Sriwijaya University, November 1995.

Hoesni, M. Hasan et al. Follow-up Study Among IUD Acceptors in Java. Jakarta: The Population Council, April 1995

Indonesian Demographers Association, Lampung. Improving Rural KB Mandiri through the CBD program of Lampung. Lampung: BKKBN Provincial Office, December 1995.

The Institute for Mass Communications Research and Development, Jakarta. Program Evaluation: Community Based Distribution (CBD) in West Java, Central Java, East Java and Bali. Jakarta: URC, March 1995

The Institute for Mass Communications Research and Development, Jakarta. Program Evaluation: Community Based Distribution (CBD) in Eight Provinces (West Java, Central Java, East Java Bali, North Sumatra, South Sumatra, Lampung and South Sulawesi" Jakarta: URC, December 1995

ISFI. Evaluation of the Referral Pharmacies and Village Contraceptive Posts in East Java. Surabaya: Ikatan Sarjana Farmasi Indonesia (ISFI, December 1995.

Joesoef, Mohamad et al. Husband's Approval of Contraceptive Use in Metropolitan Indonesia: Program Implications. Studies in Family Planning vol. 19, 3 May/June 1988: 162-168.

Kasidi, Heru and P.C. Miller. The 1991 Norplant Implant Use-Dynamics Diagnostic Study in Indonesia. Jakarta: The Population Council, May 1992.

Karsono, Rosini et al. Final Report of the Peer Review OR Project: the Feasibility of Establishing a Self Sustaining IBI Peer Review Program to Improve PSFP Services in Indonesia. Jakarta: University Research Corporation, December 10, 1993. 
Linan, Huan Wan. Final Report for Training Evaluation and Assessment Private Sector Family Planning Project. Jakarta: URC, June 1992.

Lubis, Firman et.al. "One-Year Experience with Norplant Implants in Indonesia.” Studies in Family Planning vol. 14, Number 6/7, June/July 1983.

Lubis, Firman. The Experience of Norplant Use in Indonesia. Jakarta: YKB, 1992.

Lubis, Firman et al. The Acceptance of Norplant in Indonesia: Results of Field Research. Majalah Kesehatan Masyarakat Indonesia (1), 1993.

Maas, Linda T. Improving FP Self-sufficiency through Strengthening the Role of the Village Midwives and Community Participation in North Sumatra. Medan: BKKBN Provincial Office, Faculty of Medicine, University of North Sumatra, March 1995.

MacDonald, Patricia, et al. The Peer Review Program of the Indonesian Midwives Association: Final Report of Phase Two of the Pilot Project. Jakarta: University Research Corporation, August 1995.

MacDonald, Patricia and M. Francisco. Internal Quality Assurance: An Assessment of the PKMI Pilot Project. Jakarta: Universirty Research Corporation, Dec. 1995.

Marzolf, James R. Financing Long-Term Family Planning Methods through JPKM Managed Care. Jakarta: University Research Corporation, September 1995.

Pandi, Sri Hartati et al. Operations Research Implant in North Sumatra, West Sumatra, South Sulawesi, West Java, and North Sulawesi. Jakarta: BKKBN Center, 1989.

PKMI. Efforts to Improve the Quality of Long-Term Contraceptive Services in Hospital FP Program in Indonesia. Jakarta: PKMI, 1995.

Poernomo, Ieda. Results of the Use of Norplant Research in Indonesia (Review of Socio Cultural - Psychologist Aspects). Jakarta: YKB, 1988.

Poernomo, Ieda et al. Norplant Acceptance in the Rural Areas: Qualitative Research in Kab. Temanggung, Central Java. Jakarta: YKB, 1986.

Poernama, Ieda. Users' Attitudes About Norplant Contraceptive Subdermal Implant. Jakarta: YKB, 1989.

The Population Council. Operations Research Regional Workshop on Development of the Principles of Quality of Care in Family Planning Programs in Developing Countries. Jakarta: The Population Council, February 1993.

Praptohardjo, Untung and S. Wibowo. The "U" Technique an Easiest Norplant Removal Procedures. Jakarta: BKKBN, 1992. 
Praptohardjo, Untung. One Year's Experience in Norplant Removal with the "U" Technique. Majalah Kedokteran Diponegoro 28 (3), 1993: 265-7.

Prihartono, Joedo. Operational Research Norplant Removal Study: Factors Associated with Due \& Overdue 5 Years Removal. Jakarta: YKB, 1990.

Prihartono, Joedo. Operational Research Review of Existing Norplant Implant Acceptor Tracking System. Jakarta:YKB, 1993.

Prihartono, Joedo et al. The Effectiveness of the Practical Guidance for FP Workers in the Field in Norplant Services in East Java. Jakarta: PUBIO-BKKBN, 1995.

Prihartono, Joedo et al. Community Acceptance Level Towards Secure Contraceptives Services. Jakarta: School of Medicine - University Indonesia and PUBIO-BKKBN, 1995.

Prihartono, Joedo. Norplant Surveillance System in Five Sumatra Provinces : 1991-1994. Jakarta: YKB, 1995.

Prihartono, Joedo. Sustainable Voluntary Sterilization Recommended Cost Containment Actions. Jakarta: University Research Corporation, Nov. 1995.

Raintung, Agustini et al. Safety Issues in the Provision of Injectable Contraceptive. Jakarta: The Population Council, July 1995.

Roestam, Ambar W. and Dewi S. Soemarko. Evaluation of the IISRF System, Voluntary Sterilization Program, SDES Project, Year One. Jakarta: Department of Community Medical Sciences-Faculty of Medicine, University of Indonesia, January 1996.

Roestam, Ambar W., Anindiarti; Dwi Wahyuni, Sylvia Pangemanan. Quality Sterilization Services through Mobile Service teams. Jakarta: Department of Community Medical Sciences-Medical Faculty, University of Indonesia, November 1995.

Soehartono, Soedarto, and Supriyono. Bleeding Pattern, Hormonal E2 and Progesterone Pattern among Implant Levonorgestrel Long-Term Acceptors. Surabaya: Lab/UPF Obstetrician and Gynaecologist- Faculty of Medicine, Airlangga University and Dr. Soetomo Hospital, 6 November 1992.

Sudiyono, H. Yono. Results of the Feasibility Study of Basic Health Services (Level 1) through Private Practice Doctors, General Clinic Doctors and PT ASTEK. Jakarta: Indonesian Medical Association, September 1995.

Sugiyanto, L.E. Hadjar, and U.M. Fahren. The Advantaging of Village Midwives. Jakarta: PUBIO-BKKBN, 1995.

Sujana. Development of IEC on Removals and Re-insertions of Norplant. Jakarta: School of Public Health-University Indonesia, 1996. 
Sullivan, Jeremiah et al. "Contraceptive Use-Effectiveness in Mojokerto Regency, Indonesia: A Comparison of Regular Program and Special Drive Acceptors." Studies in Family Planning vol. 7, 7 July 1977: 188-196.

Surindo Utama (PT.). Operations Research Norplant IEC Situation Analysis in Two Provinces. Jakarta: PT. Surindo Utama, 1994.

Survey Research Indonesia. Analysis of the Private Sector Capacity to Service and Supply the Indonesia Contraceptive Market. Draft. Jakarta: SRI, 1989.

Sutedi, Hermini and Jayanti Tuladhar. Quality of Norplant Contraceptive Services in Indonesia. Jakarta: The Population Council, 1993.

Sutedi, Hermini et al. A Comparative Study Between Contraceptive Pills Microdiol 30 and Microgynon 30. Jakarta: PUBIO - BKKBN, 1993.

Tacoma, M.L. The Introduction and Use of Norplant in Indonesia from A User Perspective. Jakarta: URC, 1991.

Tan, Anthony. A Study on Community Midwives. Jakarta: PUBIO - BKKBN, December 1993.

Tan, Anthony et al. Improvements in Knowledge of Norplant Implants Acceptors: An Intervention Study in W. Sumatra and W. Java. Jakarta: The Population Council, 1995.

Thapa, Shyam et al. "Efficacy of Three Variations of Periodic Abstinence for FP in Indonesia." Studies in Family Planning vol. 21, 6 Nov/Dec 1990: 327-334.

Wibowo, Adik et.al. Results of the Norplant Management Research (Action Based Norplant Research) 1987-1998. Jakarta: YKB, 1988.

Wibowo, Adik, et al. A Situation Analysis of Government Run Service Delivery Points for FP in Indonesia. Jakarta: The Population Council, August 1994.

Wirati, I.A.M, and Made Sutarga. KB Mandiri in the Rural Areas through Community Financing in Bali. Denpasar: Yayasan Duta Kencana, Februari, 1991.

Ward, Sheila et al. Service Delivery Systems and QOC In the Implementation of Norplant in Indonesia. Jakarta: BKKBN, 1990.

Widyantoro, Ninuk. "The Story of Norplant Implants in Indonesia". Reproductive Health Matters No. 3, May, 1994. 
Appendix B

\begin{tabular}{|c|c|c|c|}
\hline NO & TITLE & AUTHOR & TYPE of OR STUDIES \\
\hline 1 & $\begin{array}{l}\text { Operations Research Implant in West Java, North Sumatra, West Sumatra, South } \\
\text { Sumatra, South Sulawesi, and North Sulawesi }\end{array}$ & Sri Hartati Pandi, et.al & Exploratory \\
\hline 2 & $\begin{array}{l}\text { Results of Norplant Management Research (Action Based Norplant Research): } \\
\text { 1987-1998 }\end{array}$ & YKB & Exploratory \\
\hline 3 & Norplant Removal Study: Factors Associated With Due \& Overdue 5 years removal & Joedo Prihartono & Exploratory \\
\hline 4 & KB Mandiri in the Rural Areas through Community Financing in Bali & I.A.M Wirati \& Made Sutarga & Exploratory \\
\hline 5 & Review of Existing Norplant Implant Acceptor Tracking System & Joedo Prihartono & Exploratory \\
\hline 6 & $\begin{array}{l}\text { A Situation Analysis of the Government Run Service Delivery Points for FP in } \\
\text { Indonesia. }\end{array}$ & Adik Wibowo, et.al & Exploratory \\
\hline 7 & Follow-up Study Among IUD Acceptors in Java & Hasan.M.Hoesni, et.al & Exploratory \\
\hline 8 & Safety Issues in the Provision of Injectable Contraceptive & Agustin Raintung, et.al & Exploratory \\
\hline 9 & Secure Contraception Teams Mobile Services in D.I. Yogyakarta & Azrul Anwar & Exploratory \\
\hline 10 & $\begin{array}{l}\text { Efforts to Improve the Quality of Long-Term Contraceptive Services in Hospital FP } \\
\text { Program in Indonesia. }\end{array}$ & PKMI & Exploratory \\
\hline 11 & $\begin{array}{l}\text { Improving the Acceptance and Quality of VS Services through the Screening } \\
\text { Referral \& Follow-up of Pre and Post-VS Clients }\end{array}$ & Endang Basuki & Intervention \\
\hline 12 & $\begin{array}{l}\text { The Effectiveness of the Practical Guidance for FP Workers in the field in Norplant } \\
\text { Services in East Java.. }\end{array}$ & Joedo Prihartono & Intervention \\
\hline 13 & $\begin{array}{l}\text { Peer Review OR Project: the Feasibility of Establishing a Self Sustaining IBI Peer } \\
\text { Review Program to Improve Private Sector FP Services in Indonesia }\end{array}$ & Rosini Karsono, et.al & Intervention \\
\hline 14 & $\begin{array}{l}\text { Improving Rural KB Mandiri through Improving the Distribution of Contraceptives, } \\
\text { Private Sector Midwives and Community Participation in W. Java. }\end{array}$ & Eko Budiarto & Intervention \\
\hline 15 & $\begin{array}{l}\text { Improving Rural KB Mandiri through Improving the Role of Private Sector Midwives } \\
\text { and Rural Community Institutions in E. Java. }\end{array}$ & Kesuma Halim & Intervention \\
\hline 16 & $\begin{array}{l}\text { Improving the Role of the Private Sector Midwives through the Improvement of Rural } \\
\text { KB Mandiri in South Sumatra }\end{array}$ & Yoyok Hendarso & Intervention \\
\hline 17 & $\begin{array}{l}\text { Improving FP Self-Sufficiency through Strengthening the Role of the Village } \\
\text { Midwives and Community Participation in North Sumatra. }\end{array}$ & Linda T. Maas & Intervention \\
\hline 18 & $\begin{array}{l}\text { Improvements in Knowledge of Norplant Implant Acceptors: An Intervention Study in } \\
\text { W. Sumatra \& W. Java }\end{array}$ & Anthony Tan, et.al & Intervention \\
\hline 19 & $\begin{array}{l}\text { Improving KB Mandiri through Village Midwives and Community Participation in } \\
\text { Central Java }\end{array}$ & Darmono & Intervention \\
\hline 20 & Improving Rural KB Mandiri through Community-Based Distribution in Lampung & IPADI - Lampung & Intervention \\
\hline 21 & The 1991 Norplant Implants Use Dynamics Diagnostic Study in Indonesia & Heru Kasidi \& P. Miller & Evaluation \\
\hline 22 & The 1992 Norplant Use Dynamic Study in Indonesia & Dinan Bratakoesoema & Evaluation \\
\hline 23 & $\begin{array}{l}\text { Improving the Implementation of PPKBD Tasks in Order to Consolidate the Active } \\
\text { FP Users in West Kalimantan }\end{array}$ & Memet Agustiar & Evaluation \\
\hline 24 & Norplant Surveillance System in Five Sumatra Provinces & Joedo Prihartono & Evaluation \\
\hline 25 & Operations Research Norplant IEC Situation Analysis in Two Provinces & SURINDO & Evaluation \\
\hline 26 & Norplant Implants in Indonesia & Andrew Fisher, et.al & Evaluation \\
\hline
\end{tabular}




\section{Type of Respondents (bv gender)}

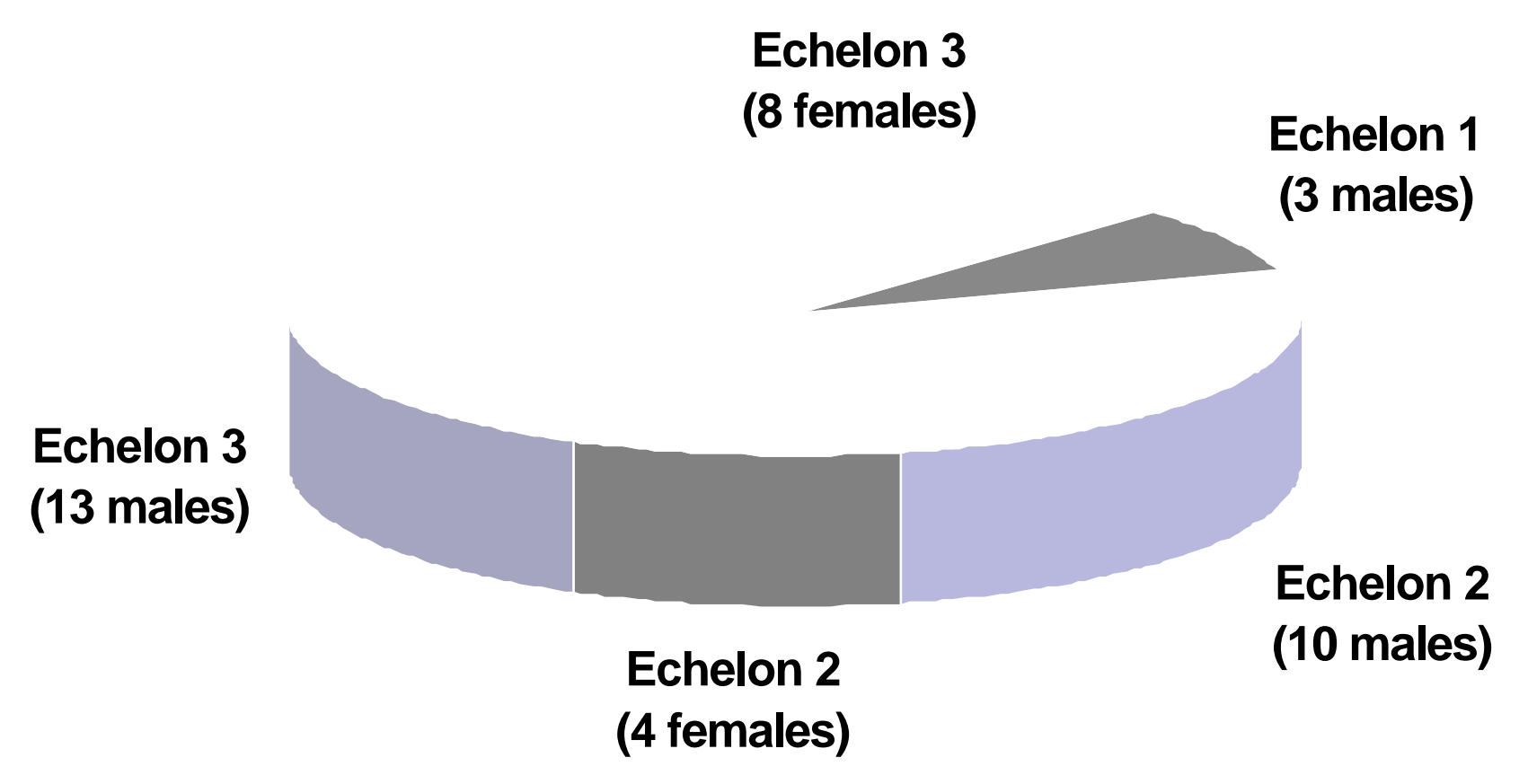




\section{Type of OR Studies in Indonesia}

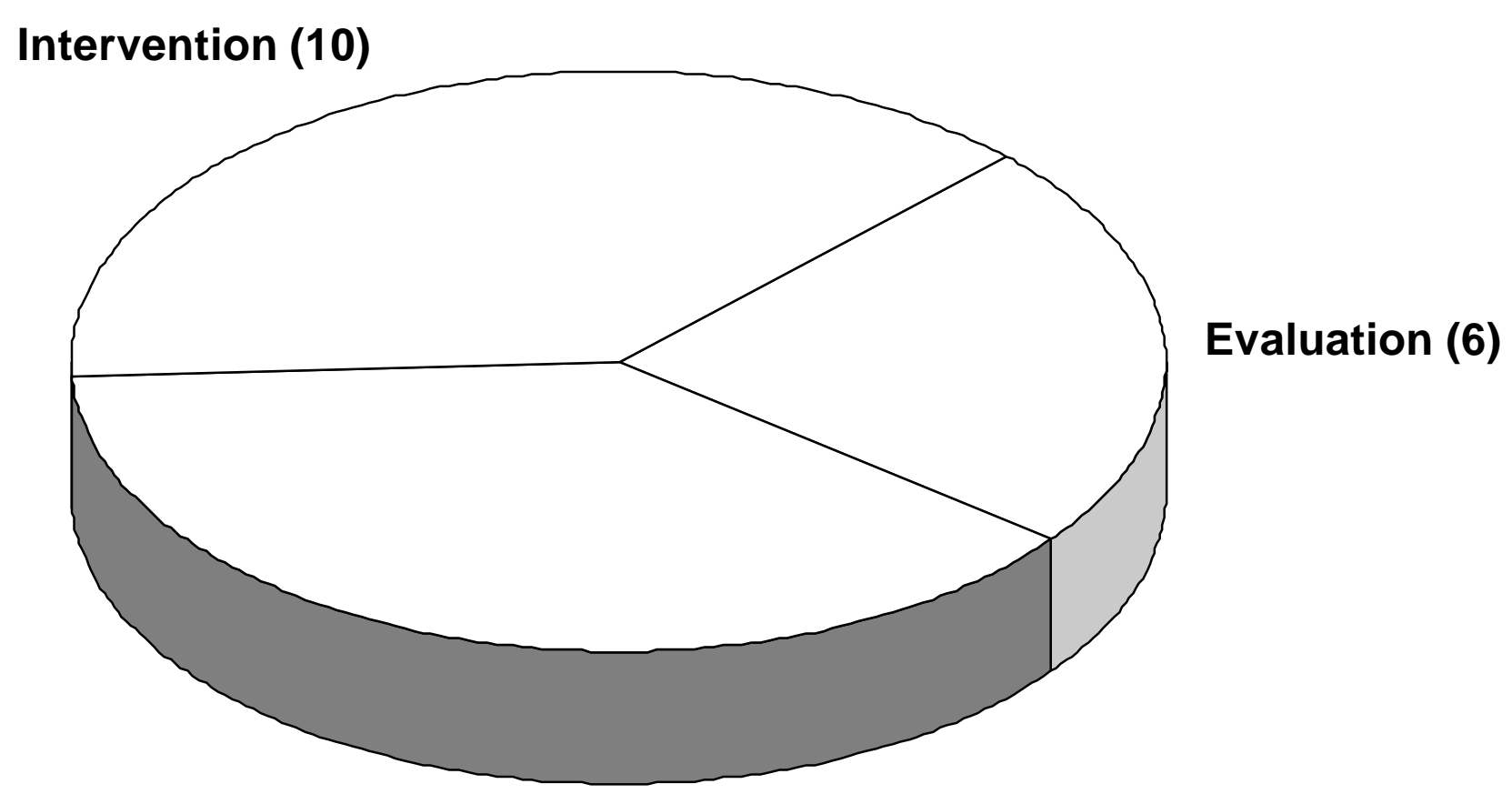

Exploratory (10) 


\section{Type of Respondents (by divisions)}

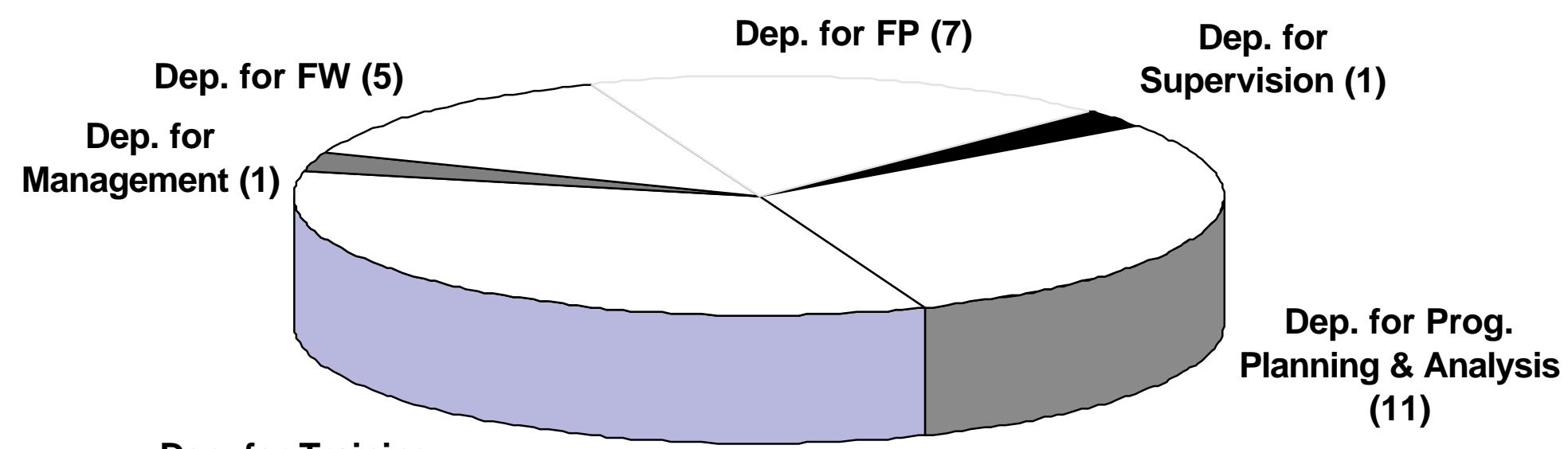

Dep. for Training

(13) 


\section{STD Diagnostic Methods}

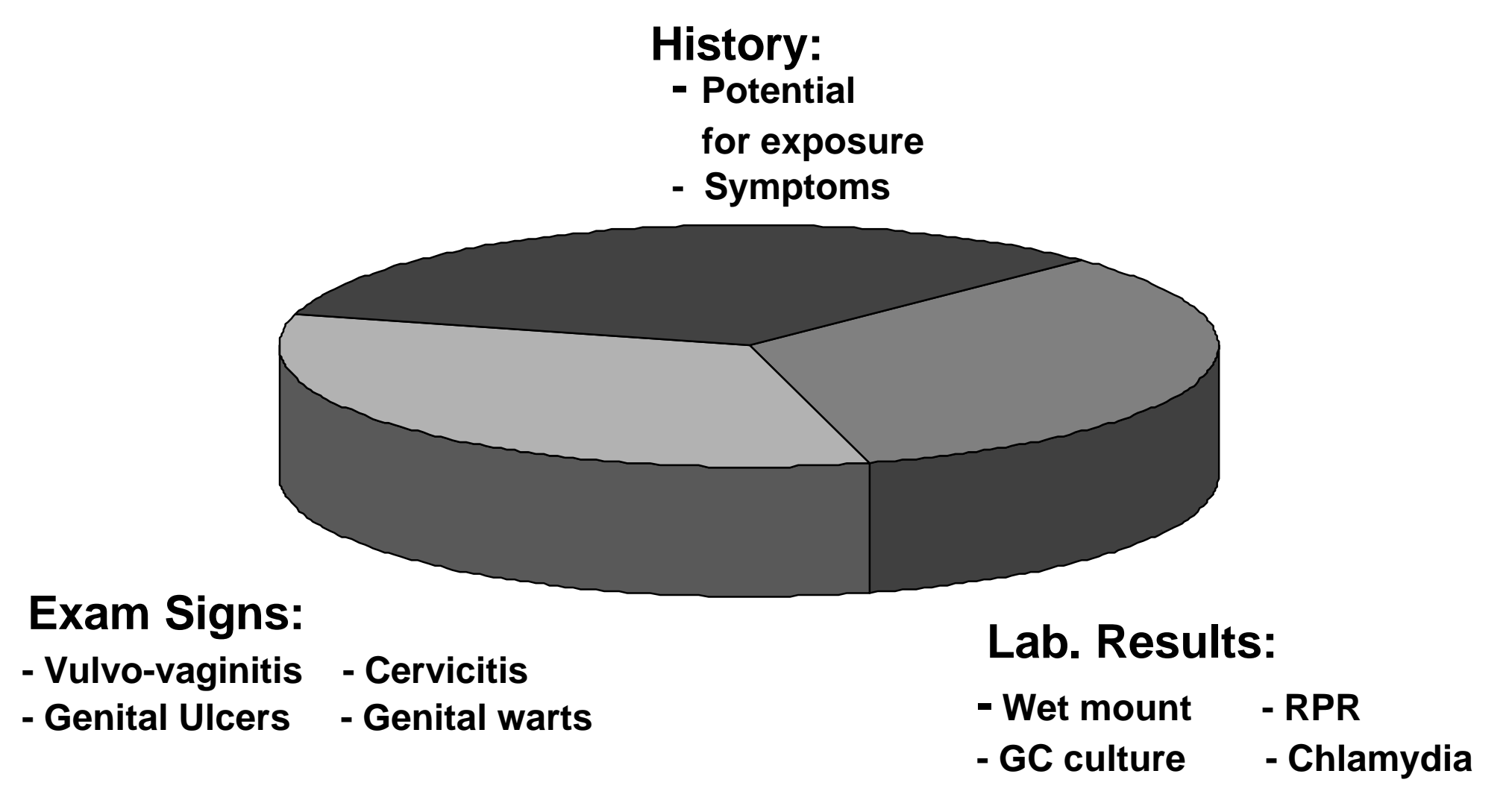




\section{List of Selected OR Studies}

No. 1

\begin{tabular}{|c|c|}
\hline Title & $\begin{array}{l}\text { Improving the Acceptance and Quality of VS Services Through the Screening Referral and } \\
\text { Follow-up of Pre- and Post-VS Clients }\end{array}$ \\
\hline Author(s) & Endang Basuki et.al \\
\hline Duration & NA \\
\hline Date of Report & September 23, 1988 \\
\hline $\begin{array}{l}\text { Institution(s) } \\
\text { Involved }\end{array}$ & Perkumpulan Kontrasepsi Mantap Indonesia \\
\hline Donor Agency & URC \& USAID \\
\hline Site(s) & Jakarta, Medan, Semarang, and Denpasar \\
\hline Methodology & $\begin{array}{l}\text { Three phase operation: (1) Problem analysis and programing of SRF (screening, referral and } \\
\text { follow up) strategies, (2) Solution testing, and (3) evaluation }\end{array}$ \\
\hline Objectives & $\begin{array}{l}\text { 1. To examine problems in the present VS SRF system and formulate an operational } \\
\text { strategy aimed at addressing these problems. } \\
\text { 2. To make the Voluntary Surgical Contraception (VS) service provision program more } \\
\text { comprehensive, and to enhance the quality of services. } \\
\text { 3. To ensure that medical and non-medical provider qualityis maintained and VS service } \\
\text { facilities are fully utilized. }\end{array}$ \\
\hline Findings & 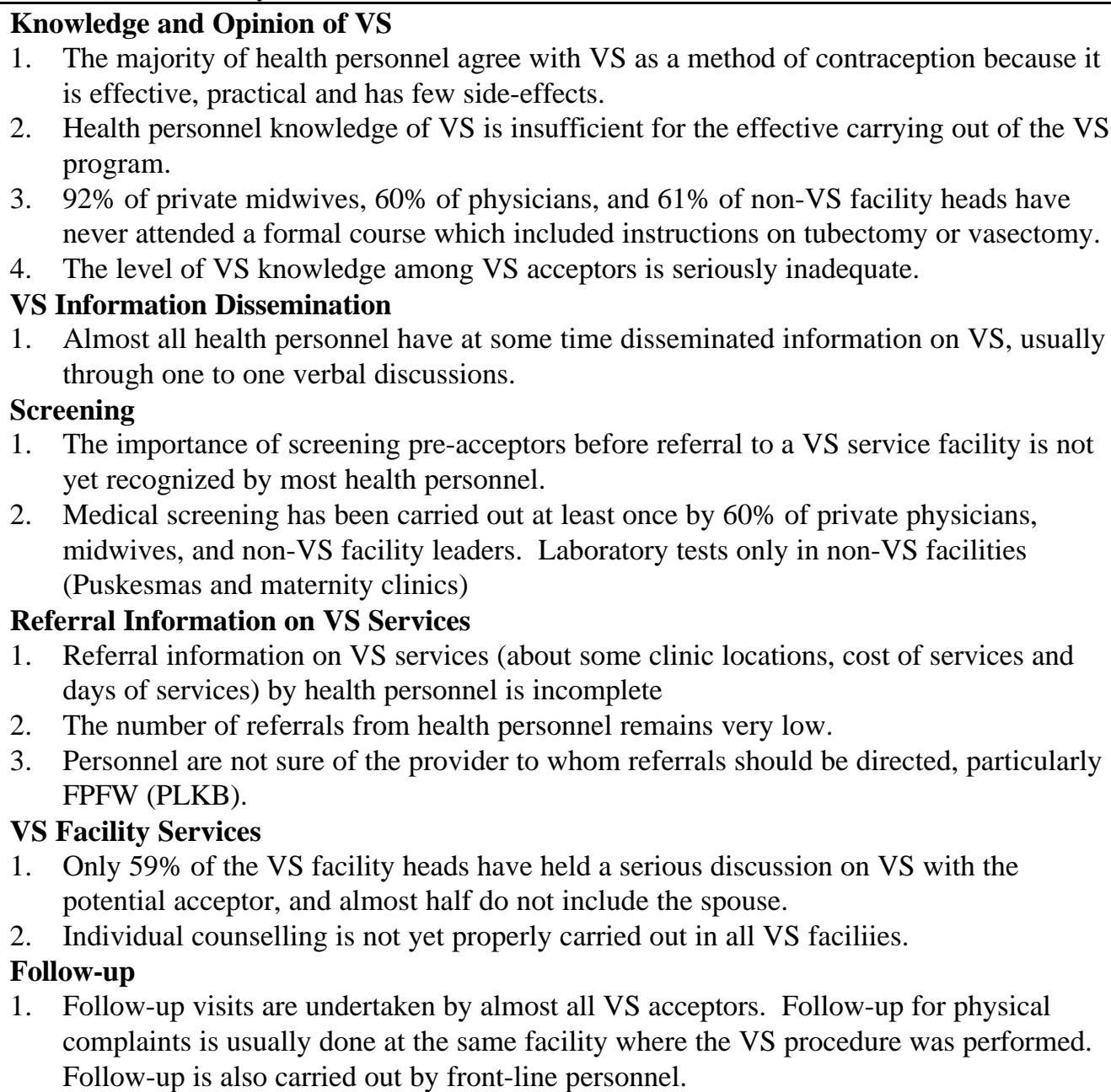 \\
\hline
\end{tabular}




\begin{tabular}{|c|c|}
\hline Recommendations & $\begin{array}{l}\text { Existing Knowledge and Opinions about VS } \\
\text { 1. The promotion of vasectomy should be intensified particularly in Medan } \\
\text { 2. Educational material is needed about sexual ability after the operation to counteract ideas } \\
\text { about frigidity. } \\
\text { 3. Educational material is needed about procedures of the operation, particularly that is } \\
\text { needed about procedures of the operation, particularly that it is simple, quick, requires } \\
\text { only a small incision, and is done on an out-patient basis. This information is needed to } \\
\text { counteract the fear of the operation. } \\
\text { Rumors Circulating about VS } \\
\text { 1. During VS training of front-line healt personnel, the development of methods to } \\
\text { overcome rumors about pregnancy failures and failing sexual performance following VS } \\
\text { is necessary. Also, IEC material developed for potential clients should include } \\
\text { information relating to persistent rumors. } \\
\text { Knowledge of VS among Front-line Health Personnel } \\
\text { 1. The training materials for FPFW and Village Contraceptive Distribution Center (VCDC) } \\
\text { should be explained: irreversibility of the medical procedure, the small possibility of } \\
\text { becoming pregnant after the operation, tubectomy is a minor medical procedure, } \\
\text { proper timing for a tubectomy and for a vasectomy, the medical procedure for } \\
\text { vasectomy is simpler than that for tubectomy. } \\
\text { Knowledge of VS services among Front-line Health Personnel: Location, Time and Cost } \\
\text { 1. The dissemination of VS service information for tubectomy and specially for vasectomy } \\
\text { should be improved. }\end{array}$ \\
\hline
\end{tabular}


No. 2

\begin{tabular}{|c|c|}
\hline Title & Research Operational Implant \\
\hline Author(s) & Sri Hartati P. Pandi et.al \\
\hline Duration & June 1988 - June 1989 \\
\hline Date of Report & 1989 \\
\hline $\begin{array}{l}\text { Institution(s) } \\
\text { Involved }\end{array}$ & BKKBN \\
\hline Donor Agency & ADB \\
\hline Site(s) & West Java, North Sumatra, West Sumatra, South Sumatra, South Sulawesi, North Sulawesi \\
\hline Methodology & Cross-sectional : Qualitative \& Quantitative approach \\
\hline Objectives & $\begin{array}{l}\text { General : } \\
\text { 1. To describe the Norplant service \& the acceptaance of Norplant in Indonesia, especially } \\
\text { in West Java, North, South \& West Sumatra, South and North Sulawesi. } \\
\text { Specific : } \\
\text { 1. To describe the means of Norplant services; } \\
\text { 2. To describe the process of Norplant services (IEC, selected acceptors in the field, } \\
\text { counseling, guidance, insertions/removals, monitoring/follow-up); } \\
\text { 3. To describe the acceptance of Norplant (knowledge, experience before \& during Norplant } \\
\text { use, experience on removals \& the fee) }\end{array}$ \\
\hline Findings & $\begin{array}{l}\text { 1. In general the manager (at provincial \& district/kodya level, subdistrict \& village level) } \\
\text { and providers knew about the effectiveness of the method, while } 67 \% \text { - } 85 \% \text { knew how } \\
\text { many women were using Norplant; } \\
\text { 2. } 60 \% \text { of Norplant acceptors knew how many capsules should be inserted; } \\
\text { 3. Only } 50 \% \text { of acceptor received information on contraindications, side-effects, process of } \\
\text { Norplant insertions; } \\
\text { 4. Most of the managers never had an orientation on Norplant; } \\
\text { 5. Only } 49.5 \% \text { of providers had ever done Norplant removals; } \\
\text { 6. Norplant insertions were done in Puskesmas \& Safari; }\end{array}$ \\
\hline Recommendations & $\begin{array}{l}\text { 1. Information on side-effects, how Norplant works, advantages \& disadvantages of } \\
\text { Norplant should be told to women completly; } \\
\text { 2. Information on contraindications, usefullness of Norplant in regard to birth planning, } \\
\text { and number of capsules should be explained to women clearly in the field; } \\
\text { 3. IEC materials (posters, flipcharts, guidance books) need to be improved; } \\
\text { 4. The logistics in place for Norplant services should be enough for one year; } \\
\text { 5. Training for providers should focus more on removals; } \\
\text { 6. Norplant should be distributed through private sectors. }\end{array}$ \\
\hline
\end{tabular}


No. 3

\begin{tabular}{|c|c|}
\hline Title & Norplant Management (Action Based Norplant Research) 1987 - 1988 \\
\hline Author(s) & Adik Wibowo, Joedo Prihartono, Firman Lubis, Sugiri Syarief, Rudi Pekerti, Harun Riyanto \\
\hline Duration & May 1987 - April 1988 \\
\hline Date of Report & December 1989 \\
\hline $\begin{array}{l}\text { Institution(s) } \\
\text { Involved }\end{array}$ & YKB, BKKBN \\
\hline Donor Agency & USAID \\
\hline Site(s) & DKI Jakarta, Central Java, East Java and South Kalimantan \\
\hline Methodology & $\begin{array}{l}\text { Qualitative (indepth interview \& observation). Sample: the decision makers at Central Level } \\
\text { (1), the decision makers at Provincial level (16), the Chief Centre of the Norplant research at } \\
\text { provincial level (3), at regency level (6), the norplant executor (53) }\end{array}$ \\
\hline Objectives & $\begin{array}{l}\text { 1. Give inputs that need to be thought in relation with the preparation to introduce implant } \\
\text { into the National Family Planning Program. Based on this purpose the research focused } \\
\text { on three factors namely: training factor for the service workers; logistic factor related } \\
\text { with supply and distribution; IEC material factor for the service workers and the acceptor } \\
\text { candidates. } \\
\text { 2. Resulted a training module for medical doctor, paramedical (midwive and nurse) and } \\
\text { Site(s)ers for the Norplant training. } \\
\text { 3. Resulted a prototype of Norplant IEC for the community/the Norplant acceptor } \\
\text { candidates for the health workers. }\end{array}$ \\
\hline
\end{tabular}




\begin{tabular}{|c|c|}
\hline Findings & 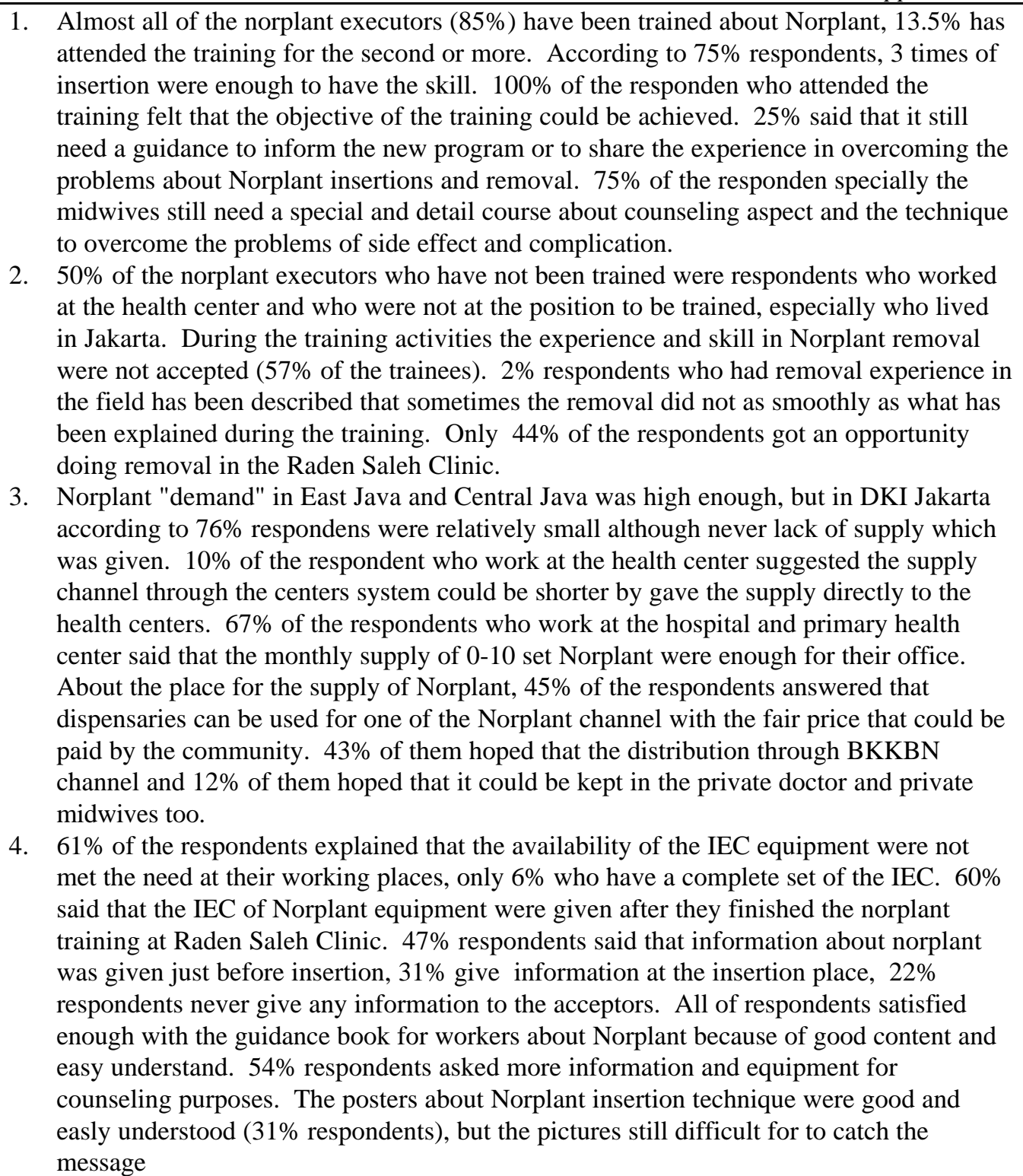 \\
\hline
\end{tabular}




\begin{tabular}{|c|c|}
\hline Recommendations & 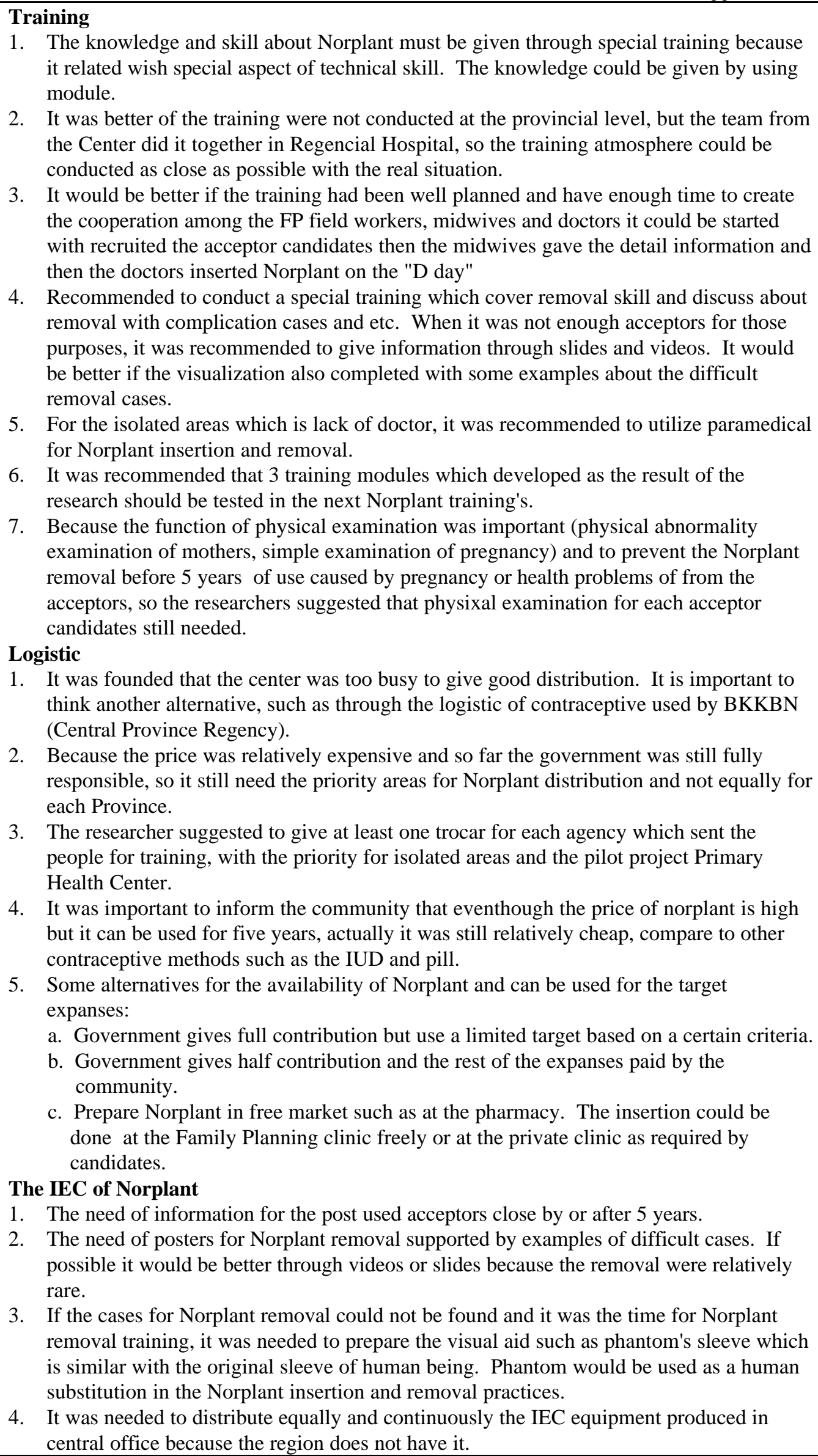 \\
\hline
\end{tabular}


No. 4

\begin{tabular}{|c|c|}
\hline Title & Norplant Removal Study: Factors Associated With Due \& Overdue 5 years \\
\hline Author(s) & Joedo Prihartono \\
\hline Duration & January - October 1990 \\
\hline Date of Report & December 1990 \\
\hline $\begin{array}{l}\text { Institution(s) } \\
\text { Involved }\end{array}$ & Yayasan Kusuma Buana \\
\hline Donor Agency & the Population Council, USAID \\
\hline Site(s) & Raden Saleh Clinic, Jakarta \& Karyadi Hospital, Semarang \\
\hline Methodology & $\begin{array}{l}\text { 1. Retrospective ( } 2,376 \text { records the registers of } 1989-1990) \\
\text { 2. Prospective Study ( } 100 \text { visitors \& } 100 \text { non visitors) }\end{array}$ \\
\hline Objectives & $\begin{array}{l}\text { 1. To evaluate completeness of } 5 \text { yrs follow up \& removal as well as factors influencing the } \\
\text { acceptors return for removal after } 5 \text { yrs of use; } \\
\text { 2. Whether or not measures are taken by the clinics to contact acceptors who didn't return } \\
\text { for removal after } 5 \text { yrs; } \\
\text { 3. Whether the women had any difficulty in obtaining removal \& remembering the due date } \\
\text { of removal; } \\
\text { 4. Recommend BKKBN steps fo follow up of acceptors not attending after } 5 \text { yrs \& } \\
\text { improvements to clinical services for women attending for removal. }\end{array}$ \\
\hline Findings & 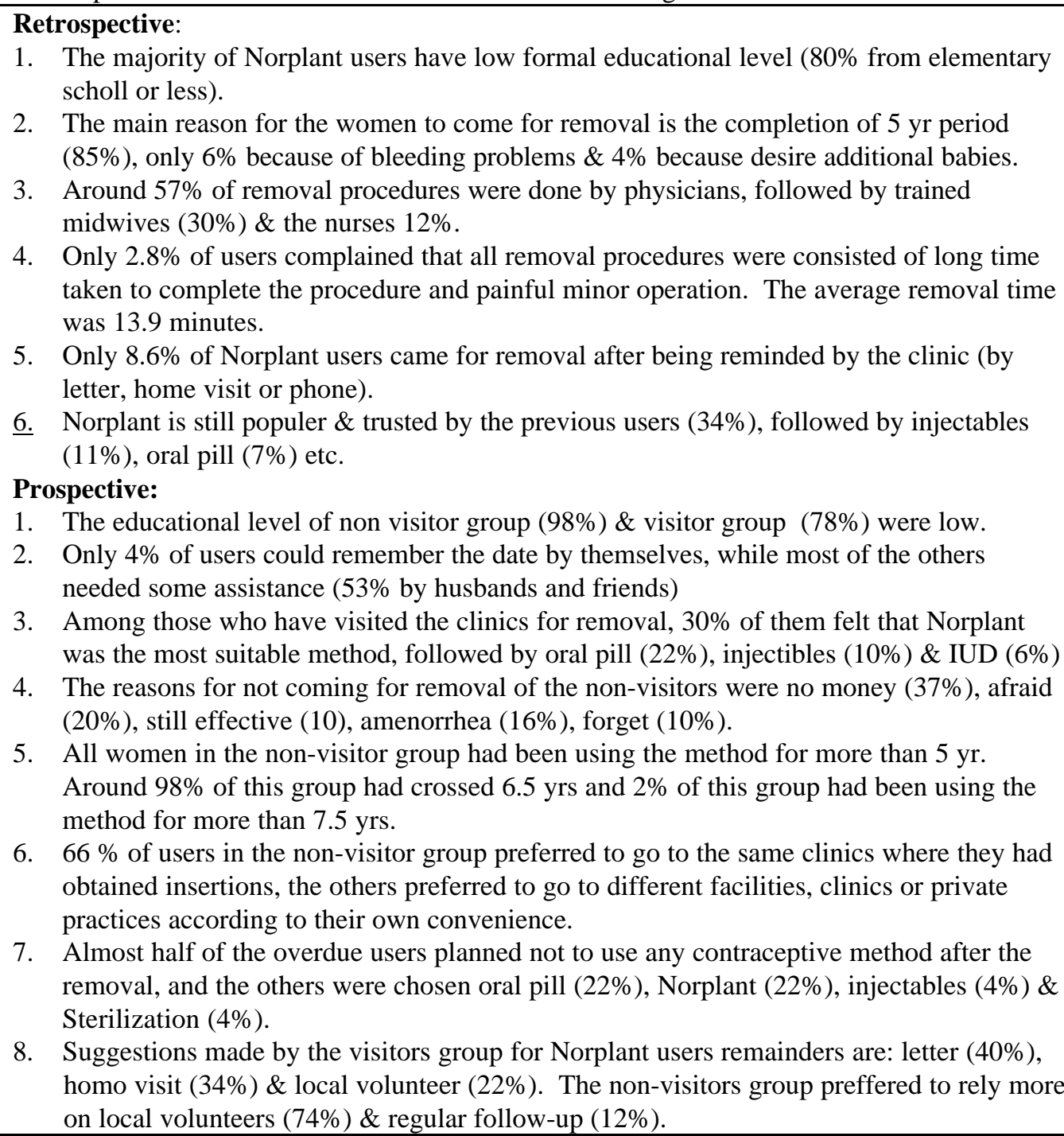 \\
\hline Recommendations & $\begin{array}{l}\text { 1. More attention should be paid to the older group \& who come from low education level; } \\
\text { 2. Tracking system that involves the participation of the existing community institution } \\
\text { should be done; } \\
\text { 3. Husband \& the close family members or friends must be involved in the mechanism to } \\
\text { remind the users of the date of removal; }\end{array}$ \\
\hline
\end{tabular}


4. The clinic staff must give much higher attention in counseling clients;

5. Clear announcements should be made to the community that the government will provide facilities for removal free or discounted cost. 
No. 5

\begin{tabular}{|c|c|}
\hline Title & KB Mandiri in the Rural Areas through Community Financing in Bali \\
\hline Author(s) & I.A.M. Wirati \& Made Sutarga \\
\hline Duration & February 1990 - December 1990 \\
\hline Date of Report & February 1991 \\
\hline $\begin{array}{l}\text { Institution(s) } \\
\text { Involved }\end{array}$ & BKKBN Provincial Office \& Yayasan Duta Kencana Denpasar \\
\hline Donor Agency & USAID \\
\hline Site(s) & Bali \\
\hline Methodology & Pilot Project Community Financing \\
\hline Objectives & $\begin{array}{l}\text { General : } \\
\text { 1. To change comunity behavior, especially FP acceptors so that they are willing to pay for } \\
\text { FP services that they receive. } \\
\text { 2. To increase the number of partial KB Mandiri acceptors who receive FP services in } \\
\text { Banjar } \\
\text { 3. To increase the target of Most Effective Methods (MKET) } \\
\text { Specific: } \\
\text { 1. To increase the percentage of acceptors who receive KB-Mandiri services } \\
\text { 2. To increase the percentage of MKET acceptors } \\
\text { 3. To increase the percentage of FP acceptors }\end{array}$ \\
\hline Findings & $\begin{array}{l}\text { 1. Not all community members know exactly about community financing. } \\
\text { 2. Supplies (injectable, pill and condom) have been used. The number of active acceptors } \\
\text { are higher than new acceptors. } \\
\text { 3. There are still barriers in collecting donations from the community and it's individual } \\
\text { members } \\
\text { 4. Most of expenditures were used for administrative support. Cases like side effects, } \\
\text { referrala to hospitals, donation for tubectomy and vasectomy, etc. do not exist yet. } \\
\text { 5. Recording \& reporting system is running well. Because of work together with FP field } \\
\text { workers. }\end{array}$ \\
\hline Recommendations & $\begin{array}{l}\text { 1. IEC for PLKB, group members, and clients need to be improved so that the idea of } \\
\text { community financing is more acceptable in the community. } \\
\text { 2. Collaboration with Puskesmas, doctors, and midwives private sector in the study areas } \\
\text { needs to be improved. } \\
\text { 3. Needs guidance from Local Goverment \& intergrated institutions.. }\end{array}$ \\
\hline
\end{tabular}


No. 6

\begin{tabular}{|c|c|}
\hline Title & The 1991 Norplant-Implant Use-Dynamics Diagnostic Study in Indonesia \\
\hline Author(s) & Heru Kasidi \& P.C. Miller \\
\hline Duration & October - December 1991 \\
\hline Date of Report & May 1992 \\
\hline $\begin{array}{l}\text { Institution(s) } \\
\text { Involved }\end{array}$ & $\begin{array}{l}\text { The Population Council, Jakarta, BKS-Penfin, Andalas University, PUBIO-BKKBN, \& } \\
\text { BKKBN Provincial Office }\end{array}$ \\
\hline Donor Agency & USAID \\
\hline Site(s) & West Sumatra, West Java \\
\hline Methodology & Dynamics Diagnostic Study \\
\hline Objectives & $\begin{array}{l}\text { 1. To suplement existing information with field-based observations on the implant program, } \\
\text { with particular reference to the issue of mass campaign service delivery; } \\
\text { 2. To obtain information to guide development of the larger Use-Dynamics Study, } \\
\text { particularly regarding the state of records keeping }\end{array}$ \\
\hline Findings & $\begin{array}{l}\text { Quality of Services } \\
\text { Medical aspects: } \\
\text { 1. Removals were sometimes difficult due to poor placement at insertion; } \\
\text { 2. Since the implant's popularity is it does not involve genital touching, providers were } \\
\text { uncertain about the need for a pelvic examination. } \\
\text { Information \& Counseling: } \\
\text { 1. Due to lack of materials, inadequate training \& lack of time providers are unable to } \\
\text { provide adequate information \& counseling; } \\
\text { 2. It was not clear what priority was given to counseling. } \\
\text { Follow-up \& Continuity: } \\
\text { 1. No routine follow-up appointments; } \\
\text { 2. Return visits rarely recorded in clinic records therefore how often users returns to clinics } \\
\text { are unknown; } \\
\text { 3. of the } 120 \text { sampled, } 17 \text { were lost to follow up: } 11 \text { had moved, } 3 \text { were not at home \& } 3 \\
\text { were not known. } \\
\text { Record-Keeping } \\
\text { 1. In W. Sumatra, clients formal names at the registration books different from their } \\
\text { informal names which is known to neighbors \& Site(s)ers; } \\
\text { 2. The K-IV card has acceptance information on the front \& space for follow-up \& removal } \\
\text { information on the back - Some K-IV forms were misfiled, the front \& the back were not } \\
\text { filed at the same place. }\end{array}$ \\
\hline Recommendations & $\begin{array}{l}\text { 1. Distribute the Norplant acceptor registers to Puskesmas. This should be done } \\
\text { retrospectively (to facilitate locating clients for removal) \& prospectively (to maintain } \\
\text { better contact \& follow up); } \\
\text { 2. Prohibition on insertions by non physicians \& in non clinical settings should be reviewed; } \\
\text { 3. Improved training for providers which emphasized on; 1) proper counseling; 2) guidelines } \\
\text { for removal \& 3) aseptic techniquep; } \\
\text { 4. A set of OR studies to determine an appropriate mix of IEC materials for health centers \& } \\
\text { communities with cost alternatives. } \\
\text { 5. Send implant specialists on a brief visit to each kabupaten by teaching \& exhorting the } \\
\text { implementation of a few key procedures, as follows: keeping \& using a log for norplant } \\
\text { acceptors; ensuring availability \& appropriate use of IEC materials; clarifying removals } \\
\text { policy; clarifying appropriate treatment for prolonged bleeding; \& improving training } \\
\text { procedures, including proper guidelines for training \& how to match supply \& demand for } \\
\text { insertions \& removals. } \\
\text { 6. A series of actions should be begun immediately, as follows: } \\
\text { 7. Determination of how many of which materials have been printed \& sent where. } \\
\text { 8. Investigation into development of the material \& the nature of testing for target }\end{array}$ \\
\hline
\end{tabular}


population.

9. Investigation into availability of funding for substantial printing \& distribution of an appropriate set of IEC materials. 
No. 7

\begin{tabular}{|c|c|}
\hline Title & $\begin{array}{l}\text { The Effectiveness of the Practical Guidance for FP Workers in the Field in Norplant Services } \\
\text { in East Java. }\end{array}$ \\
\hline Author(s) & Joedo Prihartono, Maria Anggraeni, Hitima Wardhani, Leli Asih \\
\hline Duration & $1992-1993$ \\
\hline Date of Report & 1993 \\
\hline $\begin{array}{l}\text { Institution(s) } \\
\text { Involved }\end{array}$ & PUBIO - BKKBN \\
\hline Donor Agency & World Bank \\
\hline Site(s) & East Java (District Probolinggo \& District Malang) \\
\hline Methodology & $\begin{array}{l}\text { Quasi experiment. Number of sample: } 203 \text { acceptors during pre intervention (103 acceptors in } \\
\text { Probolinggo \& } 100 \text { acceptors in Malang) and } 180 \text { acceptors during post intervention ( } 98 \\
\text { acceptors in Probolinggo \& } 82 \text { acceptors in Malang) }\end{array}$ \\
\hline Objectives & $\begin{array}{l}\text { General : } \\
\text { 1. To assist government program in improving quality of Norplant services, especially on } \\
\text { counseling. } \\
\text { Specific : } \\
\text { 1. What is the impact of giving special information before insertions on Norplant users' } \\
\text { satisfaction compare with counseling; } \\
\text { the effectiveness of the practical FP workers' guidance book in giving information, } \\
\text { especially before insertions. }\end{array}$ \\
\hline Findings & $\begin{array}{l}\text { 1. Level of knowledge on Norplant significantly increased ( } \mathrm{p}<0.05) \text { in both study sites. } \\
\text { 2. Quality of services in clinic in Probolinggo (examinations on weight, varicose veins and } \\
\text { breasts) increased, while in Malang is only examination on weight). } \\
\text { 3. Impression and satisfaction with services were significantly increased in both study sites. } \\
\text { 4. The field guidance is very usefull for FP workers, although it still needs to be revised. } \\
\text { 5. The involvement of FP workers in district level is very crucial in accepting Norplant } \\
\text { services program in the field. } \\
\text { 6. Economic factor in the community still determines accepting Norplant services. Due to } \\
\text { self reliance (Kemandirian) program, the target acceptors in Malang decreased. }\end{array}$ \\
\hline Recommendations & $\begin{array}{l}\text { 1. Distribute the manual of Norplant practical guidance for FP field workers. } \\
\text { 2. Intensive and guided training for field workers \& PPKBD to increase their involvement in } \\
\text { the quality of Norplant services. } \\
\text { 3. To develop a practical guidance book on other contraceptives to increase the quality of FP } \\
\text { program in Indonesia. }\end{array}$ \\
\hline
\end{tabular}


No. 8

\begin{tabular}{|c|c|}
\hline Title & The 1992 Indonesia Norplant Use-Dynamics Study. \\
\hline Duration & December 1991 - February 1993 \\
\hline Date of Report & March 1993 \\
\hline $\begin{array}{l}\text { Institution(s) } \\
\text { Involved }\end{array}$ & $\begin{array}{l}\text { The Population Council, Jakarta, BKS PENFIN, Andalas University, BKKBN Central \& Provincial } \\
\text { Office }\end{array}$ \\
\hline Donor Agency & USAID \\
\hline Site(s) & West Sumatra, West Java \\
\hline Methodology & Diagnostic Study \\
\hline Objectives & $\begin{array}{l}\text { Norplant Use-dynamics : } \\
\text { 1. To obtain reliable estimates of overall continuation, failure \& removal rates; } \\
\text { 2. To obtain information on frequency \& reasons for early removal of Norplant; } \\
\text { 3. To obtain information on the use of Norplant beyond the recommended five years \& reasons for } \\
\text { failing to return for five year removal. } \\
\text { Quality of Norplant Service : } \\
\text { 1. To examine the extent to which Norplant acceptors were informed regarding contraceptive choice; } \\
\text { 2. To examine the extent to which norplant acceptors were provided with information concerning } \\
\text { possible side effects, treatment, follow-up visits, \& were screened for contraindications; } \\
\text { 3. To obtain information on the frequency, types, \& treatment mechanism of post insertion; } \\
\text { 4. To examine knowledge \& practice among service providers \& field workers regarding screening, } \\
\text { counseling, side-effects, pre insertion procedures, insertion \& removal procedures inc. aseptic } \\
\text { conditions, treatment, \& follow-up mechanism; } \\
\text { Variation in use-dynamics \& Quality of Care : } \\
\text { 1. To study variations in use-dynamics \&qoc according to client characteristics, geographical location, } \\
\text { \& types \& quality of service delivery mechanisms. }\end{array}$ \\
\hline Findings & $\begin{array}{l}\text { Knowledge on Particular of Norplant Implant }(\mathbf{N}=\mathbf{3 , 1 0 7}) \\
\text { 1. } 77 \% \text { acceptors knew that Norplant Implant contained } 6 \text { capsules; } 91 \% \text { knew that the method is } \\
\text { effective for } 5 \text { years; } \& 94 \% \text { said that it should be removed at the end of } 5 \text { years; } \\
\text { 2. Only } 46 \% \text { acceptors knew that Norplant can be removed before } 5 \text { years. } \\
\text { Lost To Follow-Up } \\
\text { 1. of the } 3,107 \text { sampled, } 1,287 \text { were from W. Sumatra, } 1,820 \text { were from W. Java. In W. Sumatra there } \\
\text { were } 66 \text { lost to follow-up cases during the interview period. Of that } 66 \text { cases, } 28 \text { refused to be } \\
\text { interviewed, } 20 \text { had moved, } 2 \text { were not at home } \& 16 \text { were due to other reasons. While in W. Java } \\
\text { there were } 242 \text { due to } 162 \text { had moved, } 44 \text { were not at home } \& 37 \text { were address not found. } \\
\text { Others : } \\
\text { 1. } 5 \text { yrs continuation rate was } 55 \% \text { in W. Sumatra } \& 33 \% \text { in W. Java; } \\
\text { 2. Cumulative continuation rates at } 54,60,66,72 \text { months tend to be lower in W. Java; } \\
\text { 3. Early removal (<1 yr) is less than } 5 \% \text { in both areas; } \\
\text { 4. The proportion of the acceptors who did not show up for the } 5 \text { yrs removal is not substantial; } \\
\text { 5. The continuation rate are higher among older women, women with } 3 \text { or more living children, } \\
\text { women whose youngest child was } 3 \text { yrs or older at the time of acceptance; } \\
\text { 6. The continuation rate at the fifth yrs is low among acceptors who did not use any contraceptive } \\
\text { before Norplant; } \\
\text { 7. Cumulative continuation rate at } 3,4,5 \text { yrs are lower among acceptors who wanted more children in } \\
\text { the future than who did not want more or not sure; } \\
\text { 8. the } 5 \text { yrs continuation rate is higher among acceptors who received Norplant during } \\
\text { SAFARIs than who did not; } \\
\text { 9. the cumulative continuation rates over } 4 \text { yrs in W. Java is } 26 \% \text {, in W. Sumatra is } 14 \% \\
\text { greater among acceptorss who didn't know of the possibility of removing Noprlant before } 5 \\
\text { yrs than who knew; } \\
\text { 10. the } 5 \text { yrs continuation rate is higher among acceptors who talked to health workers } \& \text { had } \\
\text { a physical examinations before the insertions compared to acceptors who didn't talk \& did } \\
\text { not have a physical examinations; } \\
\text { 11. Level of knowledge regarding Norplant was low among providers, field workers } \& \\
\text { volunteers. }\end{array}$ \\
\hline Recommendations & $\begin{array}{l}\text { 1. Provide an IEC materials for providers \& field workers. } \\
\text { 2. Retraining of trainers. } \\
\text { 3. Small scale demonstration study to improve knowledge of providers, field workers, clients, \& } \\
\text { volunteers. } \\
\text { 4. A study to review the tracking system for removal. } \\
\text { 5. Institutionalization of the Norplant method into all training programs which has FP component }\end{array}$ \\
\hline
\end{tabular}


No. 9

\begin{tabular}{|c|c|}
\hline Title & $\begin{array}{l}\text { Improving Implementation of PPKBD Tasks in Order to Consolidate Active FP participants in } \\
\text { West Kalimantan. }\end{array}$ \\
\hline Author(s) & Memet Agustiar \\
\hline Duration & Augustus 1992 - July 1993 \\
\hline Date of Report & September 1993 \\
\hline $\begin{array}{l}\text { Institution(s) } \\
\text { Involved involved }\end{array}$ & BKKBN Provincial office \& Population Study Center \& Tanjungpura University \\
\hline Donor Agency & NA \\
\hline Site(s) & West Kalimantan (District Sanggau, Sintang and Pontianak) \\
\hline Methodology & Qualitative \\
\hline Objectives & $\begin{array}{l}\text { 1. To observe the development of PPKBDs' tasks \& function and to test what factors } \\
\text { determined their success; } \\
\text { 2. To evaluate the impacts of OR towards the development of active FP participants \& } \\
\text { PPKBD's status. }\end{array}$ \\
\hline Findings & $\begin{array}{l}\text { 1. } 30 \% \text { of PPKBDs have been working as PPKBD for more than } 8 \text { years; } \\
\text { 2. } 17 \% \text { of PPKBDs just worked as PPKBD; } \\
\text { 3. 93\% of PPKBDs had done motivation to ELCOs \& } 90 \% \text { to active FP participants; } \\
\text { 4. } 83 \% \text { of PPKBDs had distributed oral pills \& only } 63 \% \text { distributed condoms; } \\
\text { 5. Only } 13 \% \text { of PPKBDs did not made a regular report; } \\
\text { 6. } 76 \% \text { of PPKBDs had been involved/actived in Posyandu, while only } 34 \% \text { had been actived } \\
\text { in UPPKA; } \\
19 \text { of } 74 \text { PPKBDs were categorized as "very good'; } 41 \text { PPKBDs were "quite good", and } 14 \\
\text { were "not so good". }\end{array}$ \\
\hline Recommendations & $\begin{array}{l}\text { 1. Training \& guidance for PPKBD should focus on the aspects of PPKBD's tasks \& } \\
\text { function; } \\
\text { 2. Training \& guidance that could increase basic knowledge on clinical care is a strategic } \\
\text { dimension for PPKBDs to implement their duties, especially on functions of self-reliance } \\
\text { and service. }\end{array}$ \\
\hline
\end{tabular}


No. 10

\begin{tabular}{|c|c|}
\hline Title & Review of Existing Norplant Implant Acceptor Tracking System \\
\hline Duration & September - December 1993 \\
\hline Date of Report & December 1993 \\
\hline $\begin{array}{l}\text { Institution(s) } \\
\text { Involved }\end{array}$ & The Population Council, Jakarta, YKB, PUBIO-BKKBN \& BKKBN Provincial \\
\hline Donor Agency & USAID] \\
\hline Site(s) & W. Sumatra, W. Java, E. Java, NTB \\
\hline Methodology & Qualitative approach: Indepth Interview \\
\hline Objectives & $\begin{array}{l}\text { 1. To assess the readiness of provincial \& local authorities for five-year removal of } \\
\text { Norplant implants; } \\
\text { 2. To list \& describe acceptor tracking systems for five-year removal currently in use at } \\
\text { provincial \& local levels. }\end{array}$ \\
\hline Findings & $\begin{array}{l}\text { 1. The tracking system used in E. Java, W. Java \& N. Sumatra was based on a hierrachical } \\
\text { approach; } \\
\text { 2. Health center personnel rely on field workers for futher contact with due or overdue } \\
\text { clients; } \\
\text { 3. the follow-up visits by health center staff tend to be cluster around the first six months of } \\
\text { insertion; } \\
\text { 4. the Posyandu is the best location to pass on the message about removal time for educated } \\
\text { clients, the availability of K-I/KB is very useful; } \\
\text { 5. for post-partum clients, the youngest age child is the way to remember time to remove; } \\
\text { 6. the system can be worked well if the awareness of need \& the sense of belonging among } \\
\text { all levels of personnel is strong. }\end{array}$ \\
\hline Recommendations & $\begin{array}{l}\text { 1. Coordination, close supervision, \& routine meetings are important requirements for the } \\
\text { success of tracking system; } \\
\text { 2. To strengthen this system BKKBN still needs to study further its implementation with } \\
\text { intensive monitoring \& supervision. The surveillance system in five sumatra provinces } \\
\text { will be the appropriate OR activity to test this mechanism; } \\
\text { 3. This system has helped guarantee the removals in E.Java W. Java, \& some districts in } \\
\text { West Sumatra. Therefore other provinces should strengthen this mechanism. }\end{array}$ \\
\hline
\end{tabular}


No. 11

\begin{tabular}{|l|l|}
\hline Title & $\begin{array}{l}\text { Final Report of the Peer Review Operations Research Project: The Feasibility of Establishing } \\
\text { A Self-Sustaining IBI Peer Review Program to Improve Private Sector Family Planning } \\
\text { Services in Indonesia }\end{array}$ \\
\hline Author(s) & Rosini Karsono \\
\hline Duration & April 1992 - September 1993 \\
\hline Date of Report & December 10, 1993 \\
\hline Institution(s) & IBI, American College of Nurse-Midwives (ACNM), University Research Corporation (URC) \\
\hline Donor Agency & USAID \\
\hline Site(s) & Central Java \\
\hline Methodology & Pilot tested \\
\hline Objectives & $\begin{array}{l}\text { 1. To develop and test the feasibility of the establishing a self-sustaining peer review } \\
\text { program, using peer review (PR) and fundraising (FR) committees functioning within } \\
\text { local IBI chapters as a way to improve the quality of family planning (FP) services } \\
\text { provided by bidans in private practice in Indonesia. }\end{array}$ \\
\hline Findings & $\begin{array}{l}\text { 1. Peer review is feasible. All activities in the PR model can be carried out by the PR and } \\
\text { FR committees. } \\
\text { Peer review is beneficial. Peer review is useful as a model of quality assurance, for } \\
\text { identifying strengths and weakness in performance and addressing these through } \\
\text { individual feedback and continuing education for all midwives. } \\
\text { Peer review is probably sustainable if modifications are made in the peer review process. } \\
\text { The fundraising activities are able to support all the cost associated with conducting peer } \\
\text { review. }\end{array}$ \\
\hline
\end{tabular}




\begin{tabular}{|c|c|}
\hline Recommendations & 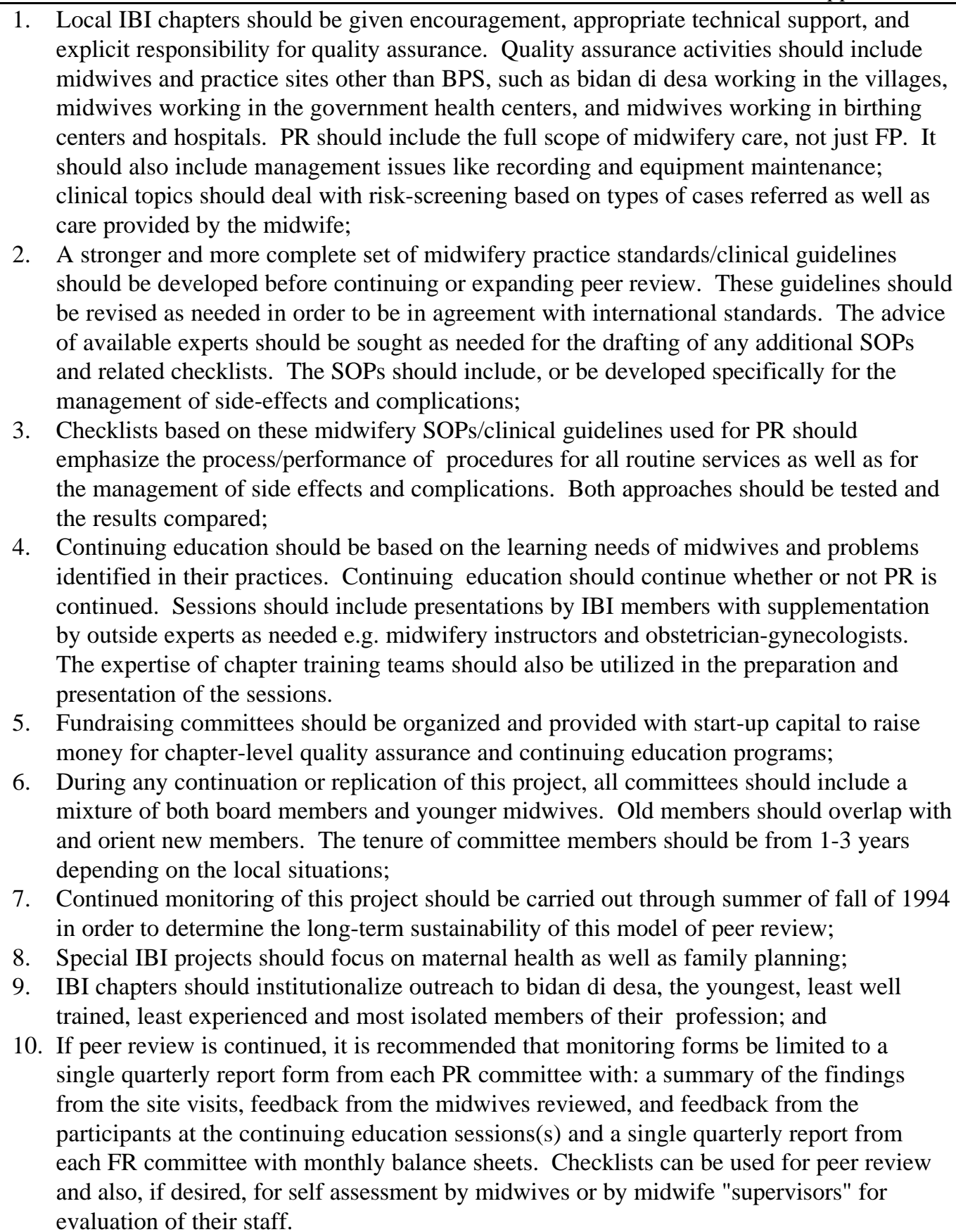 \\
\hline
\end{tabular}


No. 12

\begin{tabular}{|c|c|}
\hline Title & Norplant Surveillance System in Five Sumatra Provinces. \\
\hline Author(s) & Joedo Prihartono \\
\hline Duration & $1991-1993$ \\
\hline Date of Report & 1994. \\
\hline $\begin{array}{l}\text { Institution(s) } \\
\text { Involved }\end{array}$ & Yayasan Kusuma Buana, BKKBN \\
\hline Donor Agency & $\mathrm{ADB}$ \\
\hline Site(s) & $\begin{array}{l}\text { 1. Aceh : Kodya Banda Aceh } \\
\text { 2. Riau : Kodya Pakan Baru \& Kodya Batam } \\
\text { 3. Jambi : Kodya Jambi } \\
\text { 4. Lampung : Kodya Bandar Lampung \& Kab. Lampung Tengah. } \\
\text { 5. Bengkulu : Kod. Bengkulu }\end{array}$ \\
\hline Methodology & $\begin{array}{l}\text { Based on its field operational strategy, surveillance program can be divided to : 1) Determine } \\
\text { operational problems; 2) Development of Norplant surveillance system; 3) Intervention of } \\
\text { Norplant surveillance system; and 4) Dissemination of results }\end{array}$ \\
\hline Objectives & $\begin{array}{l}\text { General : To improve the quality of Norplant services in five Sumatra provinces. } \\
\text { Specific : } \\
\text { 1. To detect serious complications \& side effects with low incidence rates which could not be } \\
\text { detected in previous studies; } \\
\text { 2. To monitor medical service quality including insertions, follows-up, and removals; } \\
\text { 3. To monitor the quality of counseling activities for the Norplant users; } \\
\text { 4. To monitor the impact of training program on insertion \& removal; } \\
\text { To trace back those acceptors who are reaching 5-year period of use. }\end{array}$ \\
\hline Findings & $\begin{array}{l}\text { Preparational Phase : } \\
\text { 1. Conducted in } 5 \text { provinces and ending in November } 1993 \text {. } \\
\text { 2. Basically, supplies of the currently used FP MIS tools such as K-IV, R-I/KB, \& R-I/PUS } \\
\text { were enough in the five study sites. } \\
\text { Implementation Phase : } \\
\text { 1. The involvement of clinic staff in Riau in completing the matrix form was poor; } \\
\text { 2. Submission of the completed matrix form was actively done in Bengkulu, Pakanbaru, \& } \\
\text { Jambi ( } 85 \% \text {, whereas in other areas was still under } 50 \% \text {; } \\
\text { 3. In Batam, the retrieval of the completed form from the clinic site is not consistency done, } \\
\text { so the information does not provide fair comparison with other areas; } \\
\text { 4. Only Lampung, Jambi \& Banda Aceh have compiled the Norplant acceptor's register in } \\
\text { completion for Kodya level. From that register we found that in Kodya Bengkulu there } \\
\text { were } 250 \text { Norplant acceptors, } 208 \text { Norplant acceptors in Jambi \& } 185 \text { Norplant acceptors } \\
\text { in Lampung who required Norplant removal. } \\
\text { Worker involvement } \\
\text { 1. Bengkulu as a Kodya with PPKBD involvement was very high, all the PPKBDs have used } \\
\text { the ELCO's map as a tool to trace a Norplant acceptor who needs removal. They put the } \\
\text { date of removal in that map. Followed by Lampung Tengah (73\%) and Aceh (50\%). } \\
\text { Other areas were passive, especially Batam and Pakan Baru, the PPKBDs just waiting for } \\
\text { the acceptors to present themselves. } \\
\text { Factors which influenced } \\
\text { 1. Because the fee for removal in Bengkulu was expensive, that condition made acceptors } \\
\text { always report when their Norplant needed to be removed. If they reported, they just paid } \\
\text { 50\% of the total removal cost. If they did not report, they didn't get a discount; } \\
\text { 2. Because the workers in Jambi were very active in developing this surveillance system, } \\
\text { they were able to disseminate the system to other districts. } \\
\text { 3. In Batam, a weak tracking system exists because this community has an individualistic } \\
\text { rather than interdependent sytle of community interactions. }\end{array}$ \\
\hline Recommendations & $\begin{array}{l}\text { 1. Refresher training for workers at Kodya/Kabupaten and village level should be done. } \\
\text { 2. Funding for management should be allocated directly to Kodya / Kabupaten level. } \\
\text { 3. Needs for intensive monitoring, coordination, and regular meetings. } \\
\text { 4. Increase the frequency of monitoring and supervision from center. } \\
\text { 5. Additional research is needed to focus on the specific factors that promote the smooth } \\
\text { function of the Norplant surveillance system. }\end{array}$ \\
\hline
\end{tabular}


No. 13

\begin{tabular}{|c|c|}
\hline Title & Norplant IEC Situation Analysis in Two Provinces \\
\hline Author(s) & PT. Surindo Utama \\
\hline Duration & October 1992 - March 1993 \\
\hline Date of Report & 1994 \\
\hline $\begin{array}{l}\text { Institution(s) } \\
\text { Involved }\end{array}$ & PT. Surindo Utama \\
\hline Donor Agency & The Population Council, Jakarta \\
\hline Site(s) & W. Java \& W. Sumatera \\
\hline Methodology & Qualitative Research (indepth interview, FGD \& observation) \\
\hline Objectives & $\begin{array}{l}\text { General : To review the mechanism of preparation distribution and effectiveness of Norplant } \\
\text { IEC materials in Indonesia. } \\
\text { Specific : } \\
\text { 1. Availability Assessment } \\
\text { 1. Inventory and review all Norplant IEC print and audiovisual materials developed by any related } \\
\text { parties; } \\
\text { 2. Assess constraint to availability and use of print materials developed by any related parties; } \\
\text { 3. Assess the role of audiovisual media in promoting the use and understanding of Norplant; } \\
\text { 4. Assess distribution system for Norplant IEC materials at the central, provincial and district levels. } \\
\text { 2. Quality Assessment } \\
\text { 1. Select a minimum of two widely used Norplant IEC print materials and assess the quality of content; } \\
\text { 2. Assess content and quality of Norplant information exchange by the providers to acceptors; } \\
\text { 3. Decribe the method of material development. }\end{array}$ \\
\hline Findings & 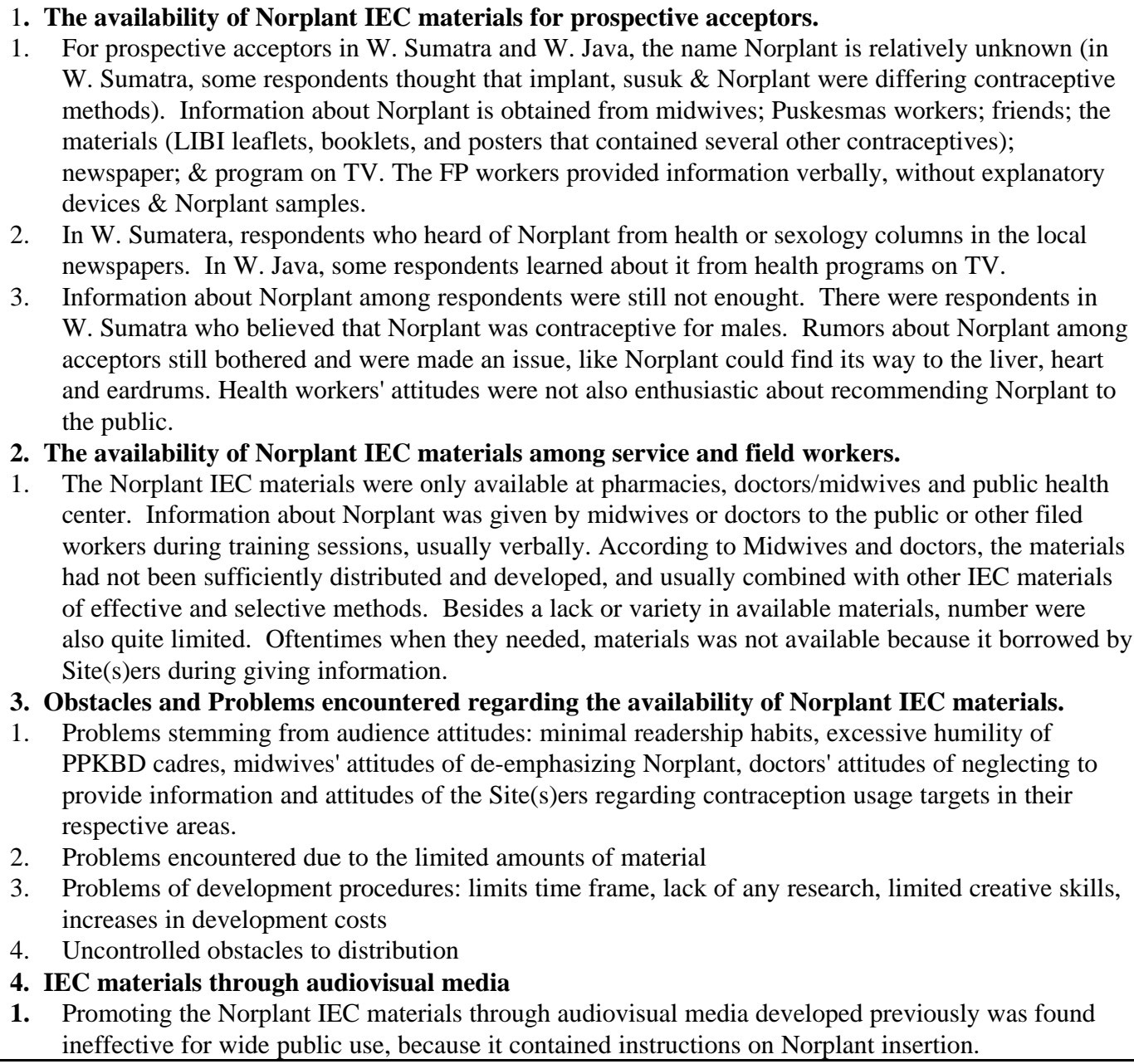 \\
\hline Recommendations & (No recommendation) \\
\hline
\end{tabular}


No. 14

\begin{tabular}{|c|c|}
\hline Title & A Situation Analysis of The Government Run Service Delivery Points for FP in Indonesia \\
\hline Duration & September 1993 - August 1994 \\
\hline Date of Report & August 1994 \\
\hline $\begin{array}{l}\text { Institution(s) } \\
\text { Involved }\end{array}$ & The Population Council, Jakarta, PUBIO - BKKBN \\
\hline Donor Agency & AVSC \\
\hline Site(s) & W. Java, C. Java, E. Java, S. Sulawesi, Lampung, N. Sumatra, S. Sumatra, W. Sumatra, NTB \\
\hline Methodology & Situation Analysis Study \\
\hline Objectives & $\begin{array}{l}\text { 1. To describe the functioning, availability, \& quality of FP service delivery at the public run } \\
\text { SDPs. }\end{array}$ \\
\hline Findings & $\begin{array}{l}\text { SDP Caseload } \\
\text { 1. Up to } 5.8 \text { FP clients visisted the SDP during the two-day visit; } \\
\text { 2. Between } 29 \text { and } 119 \text { new FP clients a month came to a SDP for FP information \& } \\
\text { services; } \\
\text { 3. As many as } 1,222 \text { visits were made to a SDP in month by FP users. } \\
\text { Client Distribution } \\
\text { 1. As many as } 60 \% \text { of the FP new clients were served by } 25 \% \text { of SDPs. } \\
\text { Client Visit } \\
\text { 1. } 62 \% \text { of those who visited the SDPs were FP users in for a regular follow-up, a follow-up } \\
\text { with problems, changing or discontinuing their method; } \\
\text { 2. } 63 \% \text { of the clients chose a long-term method. } \\
\text { Accessibility } \\
\text { 1. Some SDPs were open at } 7 \text { AM \& almost all SDPs were open at } 8: 30 \text { AM. The SDPs } \\
\text { were open for four to five hours a day for FP. Some SDPs were open for FP services } \\
\text { everyday \& some provided a few days in a week. } \\
\text { Proximity } \\
\text { 1. Between } 76 \% \& 93 \% \text { of the FP clients reside close to SDPs. It required } 27 \text { minutes for the } \\
\text { clients to reach the SDPs. } 57 \% \text { of the FP clients knew only the SDP which she was } \\
\text { visiting } \\
\text { Costs } \\
\text { 1. } 85 \% \text { of the FP clients paid for registration, contraceptive, medicine, transportation, and/or } \\
\text { other services on the day of their visit. On an avarage it cost Rp } 4,221 \text { for one person. } \\
\text { Facilities } \\
\text { 1. Between } 37 \% \text { \& } 89 \% \text { of the SDPs had piped running water; } \\
\text { 2. Nearly all had a waiting room/place \& examination room for FP clients; } \\
\text { 3. A counseling room was available at between } 39 \% \text { \& } 97 \% \text { of the SDPs. } \\
\text { 4. Between } 54 \% \text { and } 98 \% \text { had visual privacy in examination rooms/areas. } \\
\text { Equipment } \\
\text { 1. Nearly all SDPs had specula, uterine sounds, an examination table, a stethoscope, blood } \\
\text { pressure equipment, and scissors; } \\
\text { 2. Only between } 23 \% \text { and } 74 \% \text { od the SDPs had a sterilizer; } \\
\text { 3. } 63 \% \text { of the SDPs had sterilized gloves; } \\
\text { 4. Between } 64 \% \text { and } 95 \% \text { had needles \& syringes } \\
\text { (a) }\end{array}$ \\
\hline
\end{tabular}




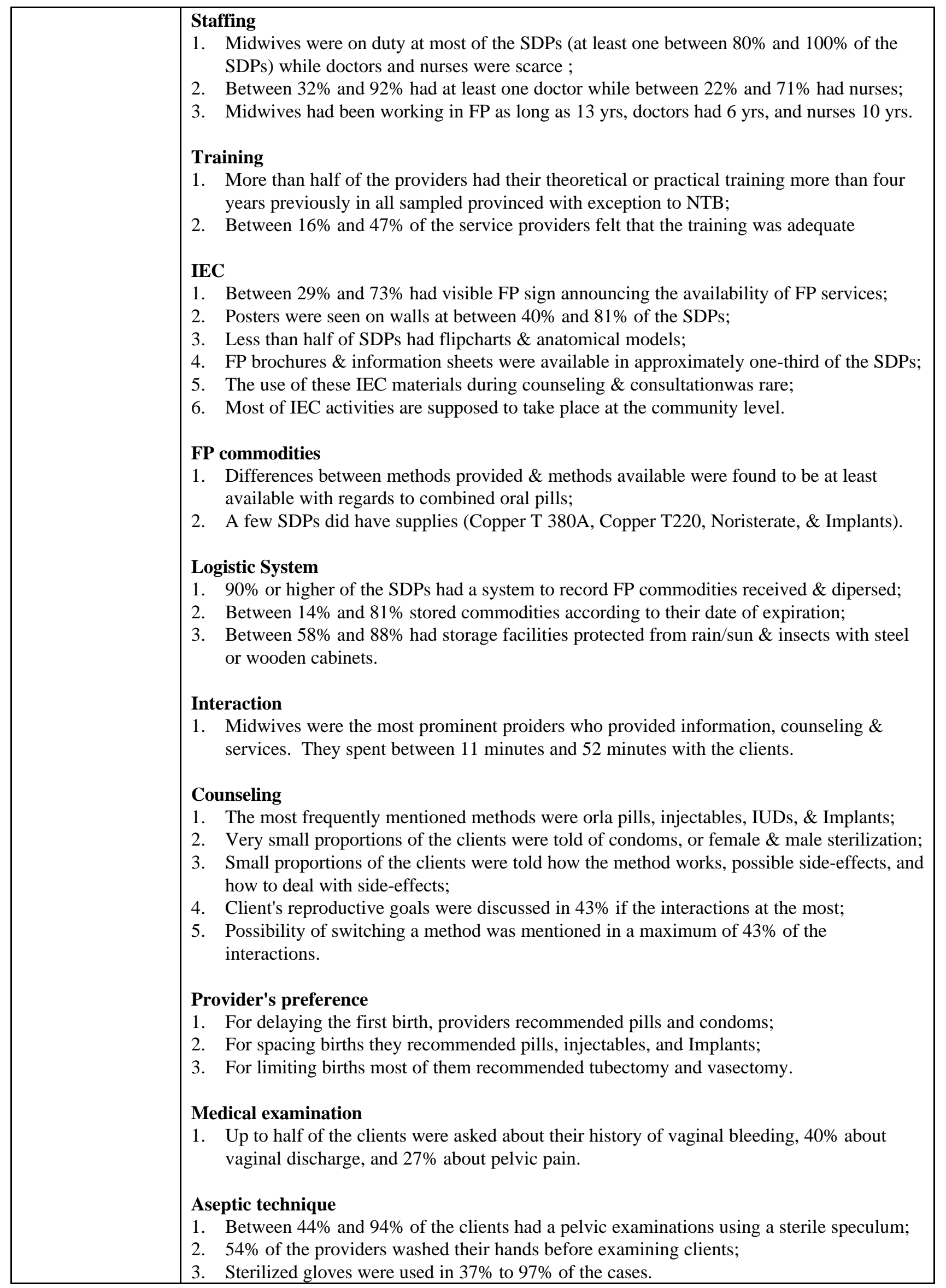




\begin{tabular}{|c|c|}
\hline & $\begin{array}{l}\text { Provider's knowledge } \\
\text { 1. Three-fourth of the providers knew that IUDs might cause heavy bleeding and spotting; } \\
\text { 2. One-third or less of them knew that clients might experience changes in menstrual } \\
\text { patterns due to Implants; } \\
\text { 3. One-third of them knew that CT } 380 \text { A was effective for } 8 \text { years. } \\
\text { Constellation of services } \\
\text { 1. A very small proportion of either the clients or the providers discussed other health issues } \\
\text { during the provider-client interactions; } \\
\text { 2. Between } 8 \% \text { and } 36 \% \text { of the clients who heard of AIDS expressed their willingness to } \\
\text { discuss it with providers. } \\
\text { Client satisfaction } \\
\text { 1. Between } 29 \% \text { and } 69 \% \text { of the FP clients who had consultation \& treatment for side-effects } \\
\text { felt that the assisstance was satisfactory; } \\
\text { 2. } 28 \% \text { felt that the waiting time was very long or long. } \\
\text { Potential LTM clients } \\
\text { 1. Small proportion of the non FP clients (potential LTM clients) knew of permanent } \\
\text { methods (a maximum of } 44 \% \text { for female sterilization); } \\
\text { 2. The percentage of those who ever used LTM (implant \& IUD) was very low (a maximum } \\
\text { of } 22 \% \text { for IUD) compared to oral pills or injectables. }\end{array}$ \\
\hline Recommendations & $\begin{array}{l}\text { A. Training } \\
\text { 1. Skill training for doctors, midwives, paramedics on LTM. } \\
\text { 2. Training to improve knowledge on LTM for FPFWs, health cadres, community, \& } \\
\text { religious leaders. } \\
\text { 3. Refreshing training focusing on discussion and find solution on problems during service } \\
\text { delivery. } \\
\text { 4. Training counseling to improve provider - client interactions \& information giving } \\
\text { activities on LTM. } \\
\text { B.Provision of equipment \& facilities. } \\
\text { C. IEC } \\
\text { 1. Provide IEC materials } \\
\text { 2. Use Mass Media - Social Marketing approach for sterilization may be considered. }\end{array}$ \\
\hline
\end{tabular}


No. 15

\begin{tabular}{|c|c|}
\hline Title & $\begin{array}{l}\text { Improving Rural KB Mandiri through Improving the Distribution of Contraceptives, Private } \\
\text { Sector Midwives and Community Participation in West Java. }\end{array}$ \\
\hline Author(s) & Eko Budiarto \\
\hline Duration & April 1993 - November 1994 \\
\hline Date of Report & 1994 \\
\hline $\begin{array}{l}\text { Institution(s) } \\
\text { Involved }\end{array}$ & BKKBN Provincial Office West Java \\
\hline Donor Agency & USAID \\
\hline Site(s) & West Java \\
\hline Methodology & Qualitative : Structured interviewed \\
\hline Objectives & $\begin{array}{l}\text { General : } \\
\text { 1. To find a way to encourage village midwives (bidan di desa) to stay at their assigned work } \\
\text { sites and also to open private practices. } \\
\text { Specific : } \\
\text { 1. To optimize the functions of the village in KB Mandiri service in rural areas. } \\
\text { 2. To know the community participation in KB Mandiri } \\
\text { 3. To know the ease of distribution and keterjangkauan of Blue Circle Gold Circle } \\
\text { contraceptives to the villages. } \\
\text { 4. To optimize the PPKBD/Sub PPKBD in referral KB Mandiri acceptors to village midwives' } \\
\text { private practice }\end{array}$ \\
\hline Findings & $\begin{array}{l}\text { 1. Midwives that stayed at their places of service have reached } 74 \% \text {, from only } 24 \% \\
\text { previously. } \\
\text { 2. FP participants reached } 84 \% \text {, the highest FP service provided by the midwives that is used } \\
\text { by the public is the injectable method at } 48 \% \text { (previosly injectable acceptor service was } \\
37 \% \text { ). } \\
\text { 3. For KB Mandiri service, } 77.4 \% \text { of the public paid (which previously was } 73.7 \% \text { ). } \\
\text { 4. The largest payments made by community members to the midwives for services (the } \\
\text { highest is Rp } 3000-4000 \text { ) reached } 28.3 \% \text {, previously it was } 17.8 \% \text { ). } \\
\text { 5. The greatest area of cooperation between midwife and PPKBD or SubPPKBD is motivating } \\
\text { ELCO }(77 \% \text { ). } \\
\text { 6. The midwives source of contraceptives from pharmacies increased } 10 \% \text { point (before it was } \\
30 \% \text {, after the evaluation it became } 40 \% \text { ). }\end{array}$ \\
\hline Recommendations & $\begin{array}{l}\text { 1. The model intervention that was is developed for this OR study be continued and developed } \\
\text { in other regencies in West Java. } \\
\text { 2. Rearrangements should be made in midwife placement is carried outr so that they stay in } \\
\text { their assigned sites through cooperation between BKKBN and the local health department } \\
\text { as well as the local government. } \\
\text { 3. PPKBD/SubPPKD should equipped with KB Mandiri IEC material media so that they } \\
\text { can intensify their activities. } \\
\text { 4. In developing their liaison worker to become a Village FP Contraceptive Post working on } \\
\text { distribution activities between the Referral Pharmacy \& the village midwives, it is best to } \\
\text { develop cooperation between ISFI (the Indonesian Pharmacists Association) and BKKBN, } \\
\text { as well as the local health departmennt. }\end{array}$ \\
\hline
\end{tabular}


No. 16

\begin{tabular}{|c|c|}
\hline Title & $\begin{array}{l}\text { Improving Rural KB Mandiri through Improving the Role of Private Sector Midwives and } \\
\text { Rural Community Institutions in East Java }\end{array}$ \\
\hline Author(s) & Kesuma Halim et al \\
\hline Duration & April 1993 - November 1994 \\
\hline Date of Report & December 1994 \\
\hline $\begin{array}{l}\text { Institution(s) } \\
\text { Involved }\end{array}$ & BKKBN Provincial Office East Java \\
\hline Donor Agency & USAID \\
\hline Site(s) & East Java \\
\hline Methodology & Intervention \\
\hline Objectives & $\begin{array}{l}\text { 1. To increase the number of KB Mandiri participants who take advantage of the services of } \\
\text { private practice midwives (BPS) } \\
\text { 2. To secure a private sector contraceptive distribution channel to the BPS and to develop a } \\
\text { mechanism to encourage community support for KB Mandiri services from the BPS. }\end{array}$ \\
\hline Findings & $\begin{array}{l}\text { 1. The number of new acceptors served by BPS after training has increased, the highest } \\
\text { percentage is } 30.4 \% \text {. } \\
\text { 2. The most popular contraceptive used by FP participants is the injectable. } \\
\text { 3. Coordination with community institutions which support midwife services is mainly in the } \\
\text { field looking for new acceptors. } \\
\text { 4. Acceptors receiving FP from midwives reached } 74.5 \% \text {, due to increases in individual } \\
\text { awareness. } \\
\text { 5. Almost all midwives }(87 \%) \text { in the intervention sites received guidance \& training from the } \\
\text { BKKBN / health team. }\end{array}$ \\
\hline Recommendations & $\begin{array}{l}\text { 1. Midwives who are to be placed in rural areas need to be equipped with sufficient } \\
\text { knowledge and skills and need to be supported with a facility and equipment to enable } \\
\text { them to develop their services. } \\
\text { 2. All midwives need to undertake their own promotion for their KB Mandiri services, in } \\
\text { addition to securing coordination with community institutions. } \\
\text { 3. Support \& supervisions }\end{array}$ \\
\hline
\end{tabular}


No. 17

\begin{tabular}{|c|c|}
\hline Title & $\begin{array}{l}\text { Improving the Role of the Private Sector Midwife through the Improvement of Rural KB } \\
\text { Mandiri in South Sumatra. }\end{array}$ \\
\hline Author(s) & Yoyok Hendarso \\
\hline Duration & April 1994 - September 1995 \\
\hline Date of Report & November 1995 \\
\hline $\begin{array}{l}\text { Institution(s) } \\
\text { Involved }\end{array}$ & the Socio-Cultural Research Center, Sriwijaya University, \& BKKBN Provincial Office \\
\hline Donor Agency & USAID \\
\hline Site(s) & South Sumatra (District Lahat \& District Mura) \\
\hline Methodology & $\begin{array}{l}\text { Pre- \& Post Interventioin. } \\
\text { Sample design : } 20 \text { midwives, } 200 \text { ELCOs, } 40 \text { community institutions }\end{array}$ \\
\hline Objectives & $\begin{array}{l}\text { 1. To increase the number of KB Mandiri participants who use Private Practice Midwives } \\
\text { (BPS) or village midwives; } \\
\text { 2. To create a contraceptive distribution channel to the BPS or village midwife; } \\
\text { 3. To improve the role of community institutions in promoting BPS/village midwife } \\
\text { services. }\end{array}$ \\
\hline Findings & $\begin{array}{l}\text { 1. } 84 \% \text { of ELCOs agreed with the KB Mandiri program; } \\
\text { 2. The injectable was the method most preferred by ELCOs ( } 30.5 \%) ; \\
\text { 3. } 86 \% \text { of ELCOs were quite satisfied with midwife services; } \\
\text { 4. Fully } 66.5 \% \text { of those who received FP services paid for them in full; } \\
\text { 5. The major contraceptive source for the midwife was IBI \& pharmacies; } \\
\text { 6. The contraceptive distribution in the pharmacy is not running smoothly \& also the price } \\
\text { is to still be expensive; } \\
\text { 7. The counseling service provided by the community institutions is still weak. }\end{array}$ \\
\hline Recommendations & $\begin{array}{l}\text { 1. To increase KB Mandiri, it is best to consider how to produce a large amount of manuals } \\
\text { for distribution to other regencies in South Sumatra; } \\
\text { 2. The PPLKB \& PLKB need to provide guidance to the PPKBD and SubPPKBD regarding } \\
\text { management of community institutions; } \\
\text { 3. For new village midwives, it would be desireble to begin thinking of their tasks \& roles in } \\
\text { providing KB Mandiri services as well as getting them motivated to look for new } \\
\text { acceptors }\end{array}$ \\
\hline
\end{tabular}


No. 18

\begin{tabular}{|c|c|}
\hline Title & $\begin{array}{l}\text { Improving Family Planning Self-sufficiency through Strengthening the Role of the Village } \\
\text { Midwives and Community Participation in North Sumatra. }\end{array}$ \\
\hline Author(s) & Linda T. Maas \\
\hline Duration & March 1994 - February 1995 \\
\hline Date of Report & March 1995 \\
\hline $\begin{array}{l}\text { Institution(s) } \\
\text { Involved }\end{array}$ & BKKBN Provincial Office North Sumatra \\
\hline Donor Agency & USAID \\
\hline Site(s) & North Sumatra \\
\hline Methodology & Qualitative \& Quantitative \\
\hline Objectives & $\begin{array}{l}\text { 1. To find a way to get the community to want to utilize the services of the village midwife } \\
\text { in order to increase the number of KB Mandiri acceptors by creating a contraceptive } \\
\text { distribution channel through the village midwife and by increasing the community's role } \\
\text { in managing the community fund. }\end{array}$ \\
\hline Findings & $\begin{array}{l}\text { 1. The potential for the the community adopting KB Mandiri is actually quite large (50\% } \\
\text { are category Family Welfare II / KS II). } \\
\text { 2. Midwives who provide FP services is also high }(73.6 \%) \text {, which is compatible with the } \\
\text { proportion of the community that believes it is the best for FP services to be provided by } \\
\text { midwives ( } 80.8 \%) \text {. } \\
\text { 3. The proportion of the community willing to pay between Rp } 3,000-5,000 \text { for service } \\
\text { costs is } 46.4 \% \text {. } \\
\text { 4. The availability of Blue Circle \& Gold Circle contraceptive is } 96.3 \% \text {. } \\
\text { 5. The information on KB Mandiri provided by community institutions is } 94.8 \% \text {, and those } \\
\text { who receive the information (ELCO community) is } 95.5 \% \text {. } \\
\text { 6. The majority of the community agreed with the community funding system (51.1\%) and } \\
\text { according to them, funds collected should be utilized for assisting the KB Mandiri } \\
(69.2 \%)\end{array}$ \\
\hline Recommendations & $\begin{array}{l}\text { 1. Continual supervision \& monitoring is needed from BKKBN toward KB Mandiri } \\
\text { management and from PPLKBs toward community institutions. } \\
\text { 2. Village midwives should be encouraged to give priority to selling Blue Circle/Gold } \\
\text { Circle contraceptives to families in the FW II, FW III, and FW III+ categories, so that } \\
\text { the provision of free contraceptives will gradually be reduced. } \\
\text { 3. Special guidance is needed from local IBI chapters toward the village midwives with } \\
\text { respect to service quality. } \\
\text { 4he existing distribution channel should be maintained, only the optimization of its } \\
\text { execution needs to be improved. }\end{array}$ \\
\hline
\end{tabular}


No. 19

\begin{tabular}{|c|c|}
\hline Title & Follow - Up Study Among IUD Acceptors of Java \\
\hline Duration & June - April 1995 \\
\hline Date of Report & April, 1995 \\
\hline $\begin{array}{l}\text { Institution(s) } \\
\text { Involved }\end{array}$ & $\begin{array}{l}\text { The Population Council, Jakarta, Diponegoro University, Airlangga University, BKS } \\
\text { PENFIN, PUBIO-BKKBN }\end{array}$ \\
\hline Donor Agency & World Bank \\
\hline Site(s) & Central Java, East Java, \& West Java \\
\hline Methodology & Diagnostic Study \\
\hline Objectives & $\begin{array}{l}\text { Estimate the percentage of IUD acceptors } \\
\text { 1. Who received follow-up care (at home or at a clinic); } \\
\text { 2. Who experienced side-effects \& type of side-effects; } \\
\text { 3. Who retained the IUD by month following acceptance \& failure rates; } \\
\text { 4. Who discontinued use \& swithched methods (incl. reinsertion at a previous clinic or a } \\
\text { different clinic); } \\
\text { 5. Determine how reported side effects \& complications were managed; } \\
\text { 6. Whether reported side effects \& discontinuation rates differ according to various socio- } \\
\text { demographic characteristics of acceptors, service type (govern. vs private) \& type of IUD }\end{array}$ \\
\hline Findings & $\begin{array}{l}\text { 1. } 60 \% \text { of IUD acceptors were using the LL \& had inserted at government SDPs (91\%); } \\
\text { 2. } 69 \% \text { knew what type of IUD they were using \& first follo-up visit should occur after one } \\
\text { week ( } 72 \%) \text {; } \\
\text { 3. Knowledge of side-effects \& how to handle were low. For those who knew about } \\
\text { possible side-effects \& what actions should be taken were higher among those women } \\
\text { who used private sources as compared to public sources; } \\
\text { 4. Almost all the acceptors were not visited by a health worker after inserted. More than } \\
\text { four-fifths of the acceptors went to see their health worker at least once after insertion, } \\
\text { while one-fifth never visited the health worker; } \\
\text { 5. } 86 \% \text { of acceptors had their IUD inserted free of charge, } 73 \% \text { had IUD removed free of } \\
\text { charge, while only } 47 \% \text { received counseling for side-effects free of charge; } \\
\text { 6. } 85 \% \text { continued to use the IUD through the first year, } 77 \% \text { through the second year, } 66 \% \\
\text { through the thord year, } 61 \% \text { through the fourth year \& } 54 \% \text { through the fifth year; } \\
\text { 7. Termination rates due to side-effects, IUD expulsion, and accidental pregnancy were } \\
\text { found to increase over the years. }\end{array}$ \\
\hline Recommendations & $\begin{array}{l}\text { 1. Copper T 380A should be given as an alternative. This IUD would result less burden on } \\
\text { the providers, managers, \& clients. } \\
\text { 2. Providers should be trained in all different type of IUD. } \\
\text { 3. FP clinics should have adequate stock of all type of IUD to give choice to potential } \\
\text { clients. } \\
\text { 4. Contact between health workers/volunteers \& clients should be improved to ensure } \\
\text { clients' good health after the insertion. } \\
\text { 5. The advantages \& disadvantages of all available IUDs and an option to switching } \\
\text { method should be informed to clients. }\end{array}$ \\
\hline
\end{tabular}


No. 20

\begin{tabular}{|c|c|}
\hline Title & Report On Norplant Implants In Indonesia \\
\hline Duration & March 1995 - April 1995 \\
\hline Date of Report & May 1995 \\
\hline $\begin{array}{l}\text { Institution(s) } \\
\text { Involved }\end{array}$ & $\begin{array}{l}\text { The Pop. Council, NY \& Jakarta; YKB; Institute of Reproductive Medicine, Santiago, Chile; } \\
\text { School of Economics, Univ. of the Philippines. }\end{array}$ \\
\hline Donor Agency & USAID \\
\hline Site(s) & Bandung \& Yogyakarta \\
\hline Methodology & Reviewed existing research \& program statistics \& interviewed key sources \\
\hline Objectives & $\begin{array}{l}\text { 1. Review past studies relating to Norplant Implant in Indonesia; } \\
\text { 2. Review various issues pertaining to Norp.Impl., inc. QOC \& services, institutional } \\
\text { capacity (public \& private sectors) to carry out insertions, removals \& Q. training; } \\
\text { 3. Develop a research proposal recommending specific areas for improvement, new } \\
\text { initiatives\& further research which will be submitted by BKKBN to the World Bank for } \\
\text { funding; } \\
\text { 4. Outline the TA requirements necessary to complete the proposed study }\end{array}$ \\
\hline Findings & $\begin{array}{l}\text { Statistical Overview } \\
\text { 1. } 1.8 \text { million women currently using the method - representing } 8-9 \% \text { of current FP users } \\
\text { or } 5 \% \text { of currently married women; } \\
\text { 2. cumulatively, insertions of norplant have exceeded } 2.6 \mathrm{~m} \text {; } \\
\text { 3. Removals - estimated needs: implant removals was not reported in national service } \\
\text { statistics until the last financial year } 1994 / 1995 \text { : BKKBN estimation: } 1 \text { ) removals } \\
\text { required in } 94 / 95 \text { ranges from } 45 \text { - } 202 \% \text { of insertions in } 89 / 90 ; 2) 166,338 \text { or } 47 \% \text { of } \\
\text { estimated removals in } 94 / 95 \text { were achieved; } 3 \text { ) about } 60,000 \text { users for overdue removals } \\
\text { (not provided removal services in } 94 / 95 \text { ) needed removals in } 95 / 96 \text {. Consultant Team } \\
\text { Estimation: 1) around } 370,000 \text { to } 385,000 \text { needed removals in } 1995 / 1996 . \\
\text { Others } \\
\text { 1. Future demand for norplant is difficult to estimate; } \\
\text { 2. Norplant services on private sector are small - the statistical information may be } \\
\text { unrealible; } \\
\text { 3. the findings \& recommendations from the past studies are pointing to the need for } \\
\text { quality improvement \& removal problem; } \\
\text { 4. An Implant Program Strategy } 1991-1994 \text { has not been uniformly implemented, } \\
\text { monitores, evaluated, or updated; } \\
\text { 5. Some provincial BKKBN staff discouraged early removal because of the high cost of } \\
\text { norplant services. Also because clients had been told that the method is a } 5 \text { yrs method, } \\
\text { they should not request removal before } 5 \text { years. }\end{array}$ \\
\hline Recommendations & $\begin{array}{l}\text { I. Link \& Match System \& Mobilizing Resources For Norplant Implant Removal } \\
\text { Management Level } \\
\text { 1. Identify a coordinating unit/team within the BKKBN that will be responsible for the } \\
\text { Norplant removal strategy. } \\
\text { 2. Increase awareness of the magnitude of the problem \& of the activities required. } \\
\text { 3. Intensified provincial level coordination organizational meetings. } \\
\text { 4. Intensified district \& sub-district level organizational meetings. } \\
\text { 5. Special removal campaigns }\end{array}$ \\
\hline
\end{tabular}


Provider Level

1. Identify Resources

2. Link trained providers with equipment, supplies, facility

3. Increase the \# of providers at all related level available for removals

4. Provide appropriate \& qualified training to midwives

5. Awareness training

6. Monitor \& evaluate

Client Level

1. Client identification

2. Match the clients in need of removal with the available trained providers

3. Back up contraception

4. Counseling

5. Information \& Education

6. Institute routine monitoring

\section{Monitoring \& Evaluation Norplant Removal Program}

1. Equipment \& supplies

2. Sentinel Surveillance System

\section{Administrative, Cost, \& Private Sector Issues}

1. Increase access to removals

2. Budget allocation

3. Coordination

4. Insertion \& removal demand projections

5. Reporting

6. Norplant implants program strategy

\section{Biomedical Issues}

1. Risk factors

2. Additional contraceptive protection

3. Contraceptive management after removal

4. Incomplete removals training

\section{Potential Research Topics}

1. A national Norplant Implants Assessment study .

2. Pilot intervention study in public \& private sector to explore the possibility of an initial insertion charge which includes removal services, particularly on improvement of managers, providers, clients' knowledge through IEC

3. Examine public \& private insurance $\&$ other schemes as a means of paying for insertion \& removal costs

4. A Norplant Implants demand projection study ( focuses on the role of public \& private in demand fulfillment. Could involve secondary data analysis \& marketing studies

5. Examine the effect of the heavy concentration of Norplant implants insertion during some months on the quality of services received by the clients

6. Study to asses $\underline{s}$ the risk of pregnancy in the 6th \& subsequent years of Norplant implants use 
No. 21

\begin{tabular}{|c|c|}
\hline Title & $\begin{array}{l}\text { Improvements in Knowledge of Norplant Implants Acceptors: An Intervention Study in West } \\
\text { Sumatra and West Java }\end{array}$ \\
\hline Author(s) & $\begin{array}{l}\text { Anthony Tan, Eman Mahdar, Faisal R. Djamal, Hafni Bachtiar, } \\
\text { Jayanti Tuladhar, R. Hasan M. Hoesni }\end{array}$ \\
\hline Duration & November 1993 - June 1995 \\
\hline Date of Report & June 1995 \\
\hline $\begin{array}{l}\text { Institution(s) } \\
\text { Involved }\end{array}$ & The Population Council, Jakarta, PUBIO-BKKBN, Andalas University, Pajajaran University \\
\hline Donor Agency & USAID \\
\hline Site(s) & West Sumatra \& West Java \\
\hline Methodology & $\begin{array}{l}\text { Quasi-experimental post-test-only Control Group Design. } \\
\text { Sample size: } \\
\text { 1. W. Sumatera: } 262 \& 364 \text { women in the experimental (P. Pariaman) \& in the control areas } \\
\quad \text { (P. Selatan); } \\
\text { 2. W. Java: } 541 \& 409 \text { women in the experimental (Majalengka) \& in the control areas } \\
\quad \text { (Cianjur) }\end{array}$ \\
\hline Objectives & $\begin{array}{l}\text { 1. To provide accurate information on Norplants implants to women before they accept the } \\
\text { implants. } \\
\text { 2. To assess the effectiveness of a system of approaches to providing information in order to } \\
\text { increase acceptor's knowledge of the implants }\end{array}$ \\
\hline Findings & $\begin{array}{l}\text { 1. In W. Java, } 25 \% \text { women in experimental areas \& } 50 \% \text { in control areas who received } \\
\text { implants were provided information on implant by midwives. About } 70 \% \text { women in } \\
\text { experimental areas \& } 70 \% \text { women in control areas were provided information by PLKBs. } \\
\text { 2. In W. Sumatra, many more women in experimental areas (65\%) \& control areas ( } 46 \% \text { ) } \\
\text { were provided information on implant by midwives. Only } 40 \% \text { in experimental areas \& } \\
29.5 \% \text { in control areas were provided information by PLKBs. } \\
\text { 3. During the first week of Implants use, proportions of women with knowledge in } \\
\text { experimental areas of W. Sumatra are higher (32\%), while in W. Java are lower (16\%). } \\
\text { 4. During third month of Implants use, proportions of women in experimental areas of W. } \\
\text { Sumatra with knowledge of implant characteristics increase (42\%), while in control } \\
\text { areas in W. Java are still higher (19\%) than in experimental areas. } \\
\text { 5. At the third month of the implant use, the proportion of women who reported } \\
\text { experiencing problems after the use of implants in experimental were } 37 \% \text { lower than in } \\
\text { control areas of W. Sumatra increase. } \\
\text { 6. Java findings are problematic, the proportion of women in experimental areas who } \\
\text { reported experiencing problems after the use of implants were } 75 \% \text { higher than in } \\
\text { control areas. } \\
\text { 7he proportion of women who were satified with the information provided to them } \\
\text { increased from } 33 \% \text { among women with low knowledge to } 90 \% \text { among women with } \\
\text { medium knowledge and } 95 \% \text { among women with high knowledge in control areas in W. } \\
\text { Java. } \\
\text { 8. The satisfied women also increased from } 34 \% \text { among women with low knowledge to } \\
77 \% \text { among women with medium knowledge in experimental areas. }\end{array}$ \\
\hline Recommendations & $\begin{array}{l}\text { 1. Midwives should be encouraged to take responsibility to do counseling, educate clients, } \\
\text { and listen to their questions. } \\
\text { 2. A cost benefit study should be conducted to assess the effect of counseling on delivery of } \\
\text { the implant services. } \\
\text { 3. Worker densities, motivation of staff, supervision, technical competence, and supplies } \\
\text { have known as barriers in the way of services. Therefore they should be looked into at } \\
\text { different institutional level to deliver user oriented health \& FP services by maintaining } \\
\text { adequate \& appropriate standards of care. }\end{array}$ \\
\hline
\end{tabular}


No. 22

\begin{tabular}{|c|c|}
\hline Title & Safety Issues in The Provision of Injectable Contraceptives \\
\hline Duration & February - June 1995 \\
\hline Date of Report & July 1995 \\
\hline $\begin{array}{l}\text { Institution(s) } \\
\text { Involved }\end{array}$ & $\begin{array}{l}\text { The Population Council, Jakarta, Indonesian Epidemiology Networks, Center for Health } \\
\text { Research, Indonesian University \& Diponegoro University. }\end{array}$ \\
\hline Donor Agency & USAID \\
\hline Site(s) & West Java, Central Java \\
\hline Methodology & Qualitative Approach \\
\hline Objectives & $\begin{array}{l}\text { 1. To conduct a review of current state of knowledge regarding provision of injection } \\
\text { services in Indonesia with relevance to the use of injectable contraceptives; } \\
\text { 2. To investigate \& describe the actual practice of providing injectable contraceptives, in } \\
\text { public \& private practice in W \& C. Java; } \\
\text { 3. To explore underlying reasons f or any lack of optimal procedures in the provision of } \\
\text { injectable contraceptive services; } \\
\text { 4. To identify the impact of poor practice based on the providers \& clients experience; } \\
\text { 5. To identify client's knowledge \& perceptions toward the health risk to themselves due to } \\
\text { improper procedures; } \\
\text { 6. To recommend interventions \& other follow-up actions to the decision makers. }\end{array}$ \\
\hline Findings & $\begin{array}{l}\text { Standard Procedure for Injectable Contraceptive Administration, Infection Control, and } \\
\text { Waste Management } \\
\text { 1. The manuals \& guidelines produced by the BKKBN, DOH, PKMI \& PB-IDI are not } \\
\text { available to the majority of service providers; } \\
\text { 2. A poster which clearly describes the steps in the provision of injectable contraceptives } \\
\text { produced by BKKBN was not found in any service points in the research area. } \\
\text { Providers Knowledge, Attitude \& Behavior } \\
\text { 1. Procedures for the provision of contraceptive injections are known by all providers, who } \\
\text { have learned this through their education in nursing/midwifery school of faculty of } \\
\text { medicine. Some have obtained additional training on contraceptive services, including } \\
\text { injectable contraceptives, through courses conducted by BKKBN; } \\
\text { 2. The standard procedure on the provision of contraceptive injection was not applied by } \\
\text { most of the providers although their knowledge about that were adequate; } \\
\text { 3. The practice of using one needle for one client (though re-using the syringe); of re-use of } \\
\text { disposable syringes; of the re-use of injecting equipment without sterilization; \& } \\
\text { neglecting other infection control procedures such as decontamination \& hand washing -- } \\
\text { are all considered all right by most providers; } \\
\text { 4. Logistics, medicine \& equipment supplies from BKKBN are not in accord with real need } \\
\text { (estimated at 50-70\% of needed); } \\
\text { 5. Supervision \& technical guidance was not done regularly by the managers in either } \\
\text { government \& private sectors; } \\
\text { 6. There is a feeling of 'regret' \& reluctance to throw away a disposable syringe \& needle; } \\
\text { 7. IEC material such as posters, guidebooks, checklists, etc did not exist in the service } \\
\text { places. }\end{array}$ \\
\hline
\end{tabular}




\begin{tabular}{|c|c|}
\hline & $\begin{array}{l}\text { Knowledge, Attitude and Behavior of Clients } \\
\text { 1. The client obtains information about contraceptive injections from other acceptors; } \\
\text { 2. Knowledge of side-effects is obtained from their experience or their friends' experience; } \\
\text { 3. Most of them did not know the standard procedure on the provision of contraceptive } \\
\text { injectables. Their experience with abscess (very rare) was considered as an accident \& } \\
\text { did not result in discontinuing use of injectable contraceptives; } \\
\text { 4. The risk of HIV infection through injections was only known by several respondents in } \\
\text { Kabupaten Pemalang. Knowledge concerning transmission of diseases through needles } \\
\text { among respondents in Kabupaten Bogor was better than Pemalang. None of the } \\
\text { respondents knew that hepatitis B could also be transmitted through unsterilized needles. } \\
\text { Logistic system } \\
\text { The currently supplied syringe is not adequate for the administering of depoprovera } \\
\text { (3cc); } \\
\text { 2. The leakage which occurs through sales of BKKBN medicines (with BKKBN labels, \& } \\
\text { supposedly free) \& which may be one cause of the shortage of supply to SDPs. } \\
\text { Service facilities } \\
\text { 1. Tables, chairs, beds, storage cupboards, hand washing container, waste containers, } \\
\text { sterilization equipment \& decontamination supplies were not always available in most } \\
\text { service places in the government sector \& small private clinics. } \\
\text { Clinical waste management } \\
\text { 1. Almost all the observed service provider sold the empty vials of medicine and in some } \\
\text { places, syringes were also sold without decontamination; } \\
\text { 2. In some places syringes \& needles were buried or burnt; several providers still separated } \\
\text { syringes from needles before disposal. In several places, used syringes \& needles were } \\
\text { thrown into general garbage containers/areas without burying \& burning. }\end{array}$ \\
\hline Recommendations & $\begin{array}{l}\text { BKKBN } \\
\text { 1. Dropping of medicine vials, syringes \& needles should be balanced at } 1: 1: 1 \text {; } \\
\text { 2. The size of syringe must match with the dosage of the injectable contraceptives being } \\
\text { provided; } \\
\text { 3. The policy of dropping "free medicine" needs investigation; } \\
\text { 4. Policy \& action should be sensitive to identifying areas which require free supplies, \& } \\
\text { have clear criteria to define who needs full, partial, or no subdization; } \\
\text { 5. The price for a pre-packaged syringe needle kit would be cheaper; } \\
\text { 6. The use of the uninject syringe which can only be used one time, should be considered; } \\
\text { 7. Guidance on contraceptive service procedures needs to be distributed ti providers at all } \\
\text { levels of service places; } \\
\text { 8. The reporting \& recording system should be improved. It's necessary to separate } \\
\text { 'complications' category from 'side effects'. } \\
\text { 9. The division of responsibilities between the technical responsibilities at the Puskesmas \& } \\
\text { program responsibilities at the BKKBN field level should be reconsiderated \& } \\
\text { clarificated; } \\
\text { 10. Minimum standards to define FP QOC should be developed; } \\
\text { 11. Guidance on a sterilization process for disposable syringe should be considered; } \\
\text { 12. IEC methods \& materials; } \\
\text { 13. The care of side-efeects \& compluications related to contraceptive use should be free of } \\
\text { charge. } \\
\text { MOH } \\
\text { 1. Dissemination of IEC to providers in all service levels regarding safety in injections } \\
\text { procedures for providers \& clients; } \\
\text { 2. Supervision guidance should be developed for managers in public \& private sector; } \\
\text { MOH should always remind \& support professional organizations (PPNI, IBI, IDI) to } \\
\text { supervise \& give professional guidance to its members. }\end{array}$ \\
\hline
\end{tabular}


No. 23

\begin{tabular}{|c|c|}
\hline Title & Secure Contraception Teams Mobile Services in Daerah Istimewa Yogyakarta \\
\hline Author(s) & Azrul Azwar \\
\hline Duration & April 1, 1994 - April 1, 1995 \\
\hline Date of Report & October 1995 \\
\hline $\begin{array}{l}\text { Institution(s) } \\
\text { Involved }\end{array}$ & Perkumpulan Kontrasepsi Mantap Indonesia \\
\hline Donor Agency & USAID \\
\hline Site(s) & Yogyakarta \\
\hline Methodology & 1) Problem Analysis; 2) Problem Solutions; and 3) Program Validation \\
\hline Objectives & $\begin{array}{l}\text { General : } \\
\text { 1. To increase the number of secure contraception participants \& the quality of secure } \\
\text { contraception services through team mobile secure contraception services in Indonesia. } \\
\text { Specific : } \\
\text { 1. To obtain the community needs assessment of secure contraceptions team mobile service } \\
\quad \& \text { their comment on DOH's letter \# } 185 / \text { MenKes/E/III/91, March } 23,1991 \text {; } \\
\text { 2. To develop and implement a model of secure contraception mobile teams services; } \\
\text { 3. To evaluate the impact of those services. }\end{array}$ \\
\hline Findings & $\begin{array}{l}\text { 1. } 86.1 \% \text { of secure contraceptions acceptors heard about the team mobile services from } \\
\text { PLKB; } \\
\text { 2. } 98.7 \% \text { of acceptors said that the place of services was easy to reach \& } 71.9 \% \text { said that te } \\
\text { service was cheap; } \\
\text { 3. } 90 \% \text { of acceptors felt satisfied with the service. }\end{array}$ \\
\hline Recommendations & $\begin{array}{l}\text { 1. The secure contraception team mobile services should be done routinely \& scheduled; } \\
\text { 2. The DOH's letter need to be reviewed. }\end{array}$ \\
\hline
\end{tabular}


No. 24

\begin{tabular}{|c|c|}
\hline Title & $\begin{array}{l}\text { Improving KB Mandiri through Village Midwives and Community Participation in Central } \\
\text { Java }\end{array}$ \\
\hline Author(s) & Darmono \\
\hline Duraion & May 1993 - October 1995 \\
\hline Date of Report & December 1995 \\
\hline $\begin{array}{l}\text { Institution(s) } \\
\text { Involved }\end{array}$ & BKKBN Provincial Office Central Java \\
\hline Donor Agency & USAID \\
\hline Site(s) & Central Java \\
\hline Methodology & Survey \\
\hline Objectives & $\begin{array}{l}\text { 1. To optimize the functions of the village midwives in conformity with their assigned FP } \\
\text { tasks. } \\
\text { 2. To increase the referral to village midwives for KB Mandiri services. } \\
\text { 3. To increase the ease of distribution of Blue Circle \& Gold Circle contraceptives to the } \\
\text { villages. }\end{array}$ \\
\hline Findings & $\begin{array}{l}\text { 1. KB Mandiri information source from midwives in the village risen by } 4.6 \% \text { (previosly } \\
\text { 3.8\% after intervention became } 8.4 \% \text { ). } \\
\text { 2. FP workers as a source of KB Mandiri information declined } 9.4 \% \text { points (from } 47.5 \% \\
\text { before the intervention to } 38.1 \% \text { after). Those who received information through TV } \\
\text { increased } 2.8 \% \text {. } \\
\text { 3. The number of active acceptors did not change, but there was an increase in FP method } \\
\text { use. Pills, injectables and IUDs, according to the ELCOs, are best obtained from the } \\
\text { village midwive. } \\
\text { 4. For the majority of ELCOs, their perception of the tasks of the village midwives as a } \\
\text { provider of health services for mothers and children, and also as a place for referrals, } \\
\text { consultation, and FP service center, increased. } \\
\text { 5. The source of contraceptive supplies for village midwives was largely from the } \\
\text { pharmacy. The total ELCOs who paid increased from } 83.1 \% \text { to } 98.9 \% \text {. } \\
\text { 6. Start up capital for the PPKBD was collected from the community self-help funding } \\
\text { activities, averaging between Rp } 25,000 \text { to Rp } 970,000 \text {. After the community was } \\
\text { mobilized to contribute, there was an increase, averaging Rp } 80,000 \text { to Rp } 3 \text { million. } \\
\text { This money was not used exclusively for FP activities, but also for the members' welfare. }\end{array}$ \\
\hline Recommendations & $\begin{array}{l}\text { 1. Village midwives need to be given the competence and means to provide advice and } \\
\text { contraceptive services to the community, including IUD and referrals. } \\
\text { 2. Self-supporting Community-based institutions in the village need to become involved in } \\
\text { the Blue Circle - Gold Circle contraceptive supply network so that it will become easier } \\
\text { for the community to obtain these contraceptives. } \\
\text { 3. The development of financing institutions with the community needs support with } \\
\text { various efforts, including the provision of incentives and working capital so that a self- } \\
\text { help funding system can be developed. }\end{array}$ \\
\hline
\end{tabular}


No. 25

\begin{tabular}{|c|c|}
\hline Title & $\begin{array}{l}\text { Efforts to Improve the Quality of Long-Term Contraceptive Services in Hospital FP Program } \\
\text { in Indonesia. }\end{array}$ \\
\hline Author(s) & Perkumpulan Kontrasepsi Mantap Indonesia (PKMI) \\
\hline Duration & Januari $1993-1995$ \\
\hline Date of Report & 1995 \\
\hline $\begin{array}{l}\text { Institution(s) } \\
\text { Involved }\end{array}$ & PKMI \\
\hline Donor Agency & USAID \\
\hline Site(s) & Jakarta \\
\hline Methodology & 1) Problem Analysis; 2) solution development; and 3) solution validation \\
\hline Objectives & $\begin{array}{l}\text { General : } \\
\text { 1. To increase the quality of long term contraceptive services in hospital FP program in } \\
\text { Indonesia. } \\
\text { Specific : } \\
\text { 1. To learn about the basic principles of a quality assurance program that has already been } \\
\text { implemented for long term hospital contraceptive services in; } \\
\text { 2. To determine the efforts that are necessary in order to be able to implement a hospital } \\
\text { quality assurance program; } \\
\text { 3. To identify the factors that must be considered in the implementation of quality } \\
\text { assurance programs; } \\
\text { 4. To document the impact of a quality assurance program on the quality of long term } \\
\text { hospital contraceptive services. }\end{array}$ \\
\hline Findings & $\begin{array}{l}\text { 1. The implementation of the basic principle of quality assurance, particularly on long } \\
\text { term method services was still rare in the study hospitals; } \\
\text { 2. The knowledge and the practice of the service providers toward the basic concept and } \\
\text { activities of a quality program were still poor; } \\
\text { 3. The attitude of the service providers toward the basic concept \& activities of the quality } \\
\text { assurance program in general was positive, except toward the concept of an incentive } \\
\text { and/or disincentive system for the quality of services. }\end{array}$ \\
\hline Recommendations & $\begin{array}{l}\text { I. Theoritical Implications } \\
\text { 1. For hospitals who have difficulty in implementing the PPM it recommended to use an } \\
\text { integration of } 3 \text { concepts of management (team approach/team work; group decision } \\
\text { making; and problem solving cycle); } \\
\text { 2. To implement the intervention program into a three package training program - 1) a } \\
\text { Quality Assurance Orientation for managers; 2) a Quality Assurance Training and 3) a } \\
\text { one-day seminar for those who were not involved in a quality assurance team but did } \\
\text { conduct the long term method services. } \\
\text { 3. To use an external facilitator that can be substituted with an internal facilitator as long } \\
\text { as the internal facilitator can work together, has adequate knowledge and skills of } \\
\text { concepts, PPM activities and technical procedures. } \\
\text { 4. Lessons on basic survey, simple statistics, concept of causality, criteria for select } \\
\text { problem priority \& problem causes, and simple planning basics need to considered } \\
\text { when training a quality assurance team. } \\
\text { II. To Improve the Quality of Hospital FP Programs } \\
\text { 1. BKKBN has to take an initiative so a quality assurance can be done in every hospital } \\
\text { who does the long term method services. } \\
\text { 2. BKKBN should develop training for a quality assurance for the hospital manager who is } \\
\text { responsible in long term method services. }\end{array}$ \\
\hline
\end{tabular}


No. 26

\begin{tabular}{|c|c|}
\hline Title & Improving Rural KB Mandiri through the CBD Program of Lampung. \\
\hline Author(s) & IPADI, Lampung \\
\hline Duration & April 1994 - October 1995 \\
\hline Date of Report & December 1995 \\
\hline \begin{tabular}{|l|} 
Institution(s) \\
Involved
\end{tabular} & IPADI, Lampung, and BKKBN Provincial Office Lampung \\
\hline Donor Agency & USAID \\
\hline Site(s) & Lampung \\
\hline Methodology & Evaluation \\
\hline Objectives & $\begin{array}{l}\text { To develop a KB Mandiri contraceptive distribution system (Blue Circle, Gold Circle, } \\
\text { other non-program contrceptives) so that these contraceptives can be distributed } \\
\text { smoothly to the villages that have a high potential to become Mandiri so the } \\
\text { contraceptive distribution model can be created for Lampung province. }\end{array}$ \\
\hline Findings & $\begin{array}{l}\text { 1. Type of contraceptives used in the survey area are injectables (30.6\%), pills (29.5\%), } \\
\text { IUDs (20.4\%) and Implants (17.3\%). } \\
\text { 2. The sources of service source first visits are: private service (38.7\% - which is mostly } \\
\text { midwife service at } 33.6 \%) \text {, and government service (53.1\%, mostly Health Centers). } \\
\text { But the source is different for revisits: private is } 42.5 \% \text { \& government is } 42.6 \% \text {. } \\
\text { 3. } 26.3 \% \text { of ELCOs believe that range of contraceptives available from the village midwife } \\
\text { is quite adequate. But } 55.3 \% \text { suggest that it would be best if contraceptives were } \\
\text { available at the nearest place. } 13.2 \% \text { said that overall the supply of contraceptives in the } \\
\text { villages are sufficient. } \\
\text { 4. The source of supply for the midwives are drug stores }(47.1 \%) \& \text { distributor }(17.7 \%) \text {. }\end{array}$ \\
\hline Recommendations & (No Recommendation) \\
\hline
\end{tabular}

